\title{
You Have Got a Fast CAR: Chimeric Antigen Receptor NK Cells in Cancer Therapy
}

\author{
Aline Pfefferle ${ }^{1,2, *(\mathbb{D})}$ and Nicholas D. Huntington ${ }^{1,2}$ \\ 1 Biomedicine Discovery Institute and the Department of Biochemistry and Molecular Biology, \\ Monash University, Clayton, VIC 3800, Australia; nicholas.huntington@monash.edu \\ 2 oNKo-Innate Pty Ltd., Clayton, VIC 3800, Australia \\ * Correspondence: aline.pfefferle@monash.edu
}

Received: 25 January 2020; Accepted: 12 March 2020; Published: 17 March 2020

check for updates

\begin{abstract}
The clinical success stories of chimeric antigen receptor (CAR)-T cell therapy against B-cell malignancies have contributed to immunotherapy being at the forefront of cancer therapy today. Their success has fueled interest in improving CAR constructs, identifying additional antigens to target, and clinically evaluating them across a wide range of malignancies. However, along with the exciting potential of CAR-T therapy comes the real possibility of serious side effects. While the FDA has approved commercialized CAR-T cell therapy, challenges associated with manufacturing, costs, and related toxicities have resulted in increased attention being paid to implementing CAR technology in innate cytotoxic natural killer (NK) cells. Here, we review the current landscape of the CAR-NK field, from successful clinical implementation to outstanding challenges which remain to be addressed to deliver the full potential of this therapy to more patients.
\end{abstract}

Keywords: natural killer cells; chimeric antigen receptors; immunotherapy

\section{Background of Chimeric Antigen Receptors}

In 1986, Steven Rosenberg harnessed the potential of tumor-specific T cells to treat melanoma patients, starting a new chapter of cell-based therapy for cancer patients [1]. While the process of harnessing tumor-infiltrating lymphocytes (TIL) is logistically challenging, generating and expanding $\mathrm{T}$ cells specific to a patient's neo-antigen is equally challenging. Therefore, TIL-based therapy has major limitations and is a perfect example of patient-specific treatment [2]. An alternative to TIL-based therapy is to genetically engineer the $\mathrm{T}$ cell receptor (TCR) to confer specificity to a particular tumor target, aptly named a chimeric antigen receptor (CAR). Although CAR therapy is still patient-specific, due to the use of T cells which need to be human leukocyte antigen (HLA)-matched, the CAR construct itself is tumor-specific [3]. The ground-breaking work of redirecting T cell specificity through genetic engineering was performed at the Weizmann Institute by Zelig Eshhar, who went on to develop a first-generation CAR at the National Institute of Health in Steven Rosenberg's lab [4,5]. The addition of co-stimulatory domains to improve the potency of CAR signaling was developed by Michel Sadelain, giving rise to second- and third-generation CAR constructs (Figure 1a) [6].

CAR constructs are made up of four main components: the single-chain variable fragment ( $\mathrm{scFv})$, the hinge, the transmembrane domain (TM), and the intracellular signaling domains. Each of the four components has been studied and optimized in $\mathrm{T}$ cells to maximize tumor detection, $\mathrm{T}$ cell activation, and tumor elimination [7]. 
(a)

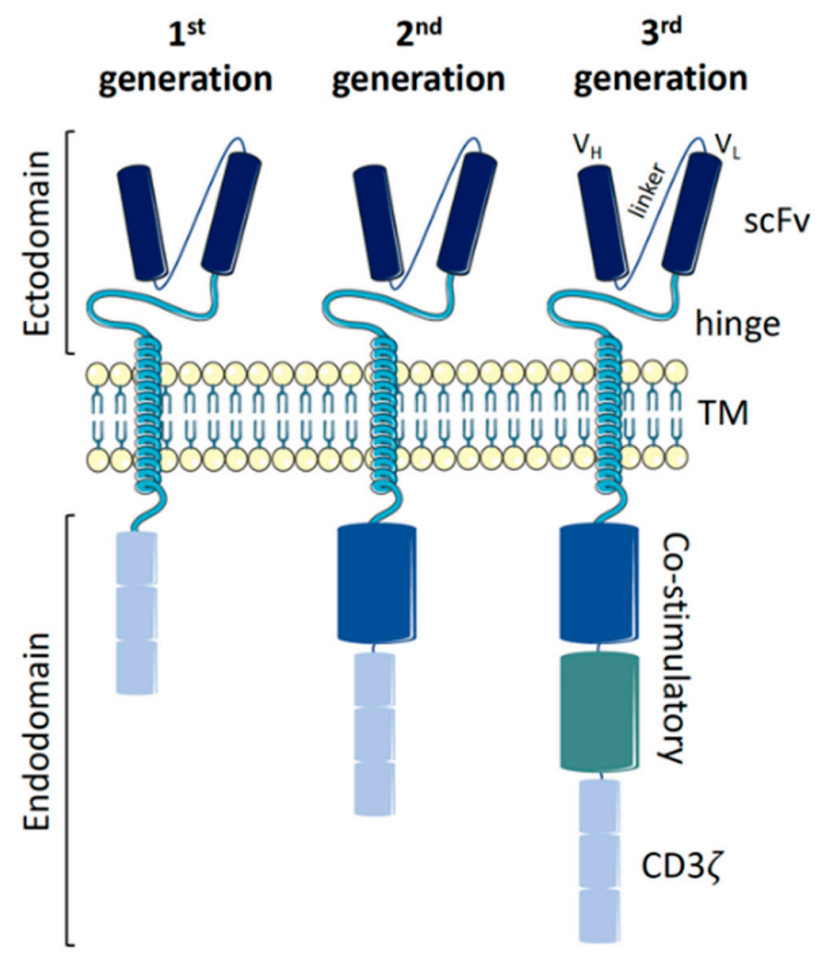

(b)

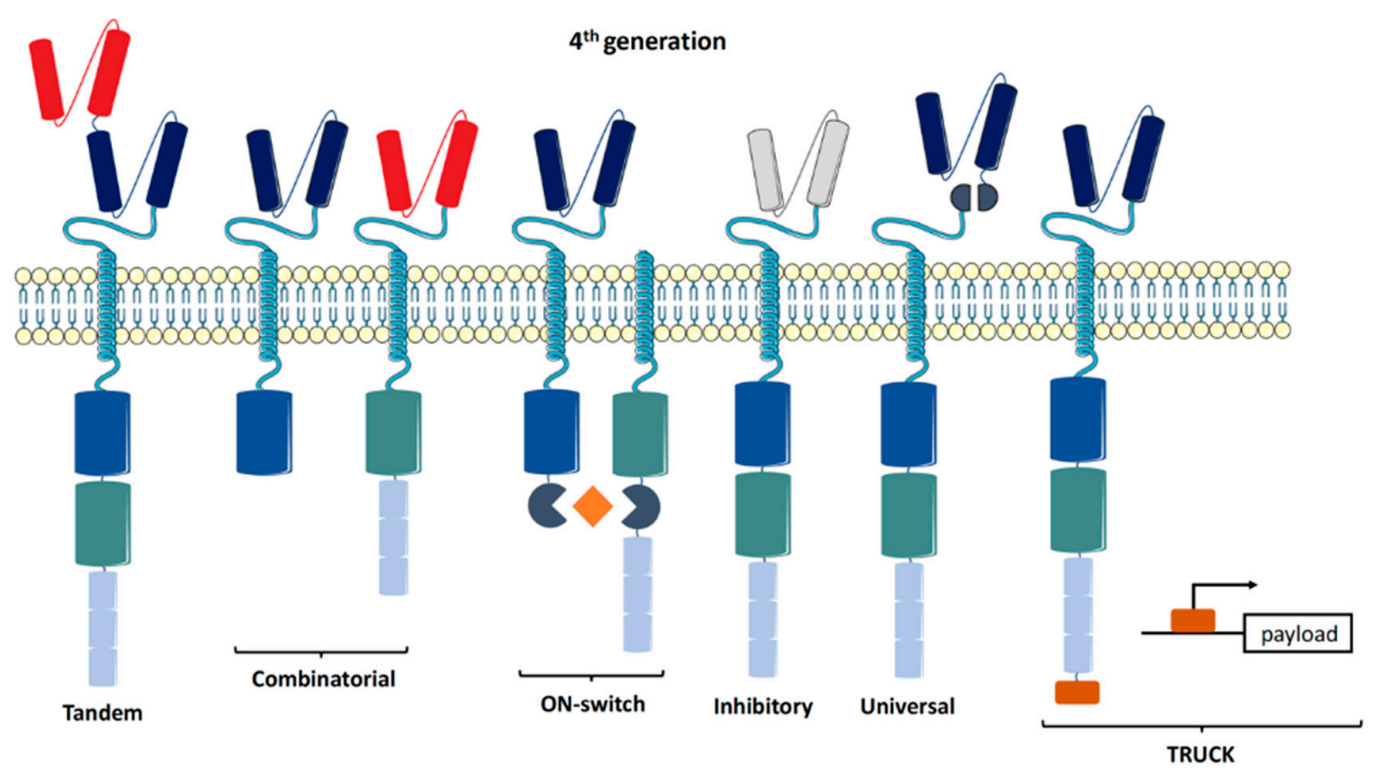

Figure 1. Evolution of chimeric antigen receptor (CAR)-T cell constructs. The main components of a chimeric antigen receptor and its evolution over time. (a) 1st, 2nd and 3rd generation CAR constructs; (b) Examples of 4th generation CAR construct organized by subgroups. Abbreviations: $\mathrm{scFv}$, single-chain variable fragment; TM, transmembrane; TRUCK, T cells redirected for universal cytokine killing.

\subsection{Ectodomains}

The $s c F v$, the antigen binding component conferring specificity, consists of a heavy $\left(\mathrm{V}_{\mathrm{H}}\right)$ and light $\left(\mathrm{V}_{\mathrm{L}}\right)$ variable fragment connected by a flexible linker. The order of the variable fragments, as well as the length of the linker, have been shown to affect the antigen binding affinity and stability of the construct. Both the epitope location and abundancy need to be considered when designing the scFv [8]. 
The length of the hinge region is important for the formation of the immune synapse. Depending on the antigen distance from the cell surface, the hinge length needs to be adjusted to allow for an optimal distance between the effector and target cell. A longer hinge provides increased flexibility to reach membrane-proximal antigens, while shorter hinges suffice for membrane-distal antigens $[9,10]$. Amino acid sequences from $\mathrm{CD} 28$ or $\mathrm{CD} 8 \alpha$ are commonly used, as well as $\mathrm{CH} 2$ and $\mathrm{CH} 3$ domains from IgG1, 2, or 4. While both $\mathrm{CH} 2$ and $\mathrm{CH} 3$ domains can also be utilized to detect CAR expression on the cell's surface, binding between $\mathrm{CH} 2$ domains and $\mathrm{Fc} \gamma$ receptors has been observed and can lead to off-target activation $[8,11]$.

\subsection{Transmembrane Region}

The transmembrane (TM) domain consists of a hydrophobic alpha helix that spans the cell membrane and anchors the CAR construct. While CD $8 \alpha$ and CD28 are most commonly used to date, the choice of TM domain has been shown to affect the functionality of the CAR construct mediated through the degree of cell activation. A CD28-derived TM domain was more prone to induce activation-induced cell death (AICD) in T cells compared to a CD8 $\alpha$-derived TM domain, while a CD3ろ-derived TM domain facilitated CAR dimerization with endogenous TCRs, leading to T cell activation $[12,13]$.

\subsection{Endodomains}

The evolution of the CAR construct has primarily focused on optimizing the intracellular signaling domains, with the first three generations of CAR constructs referring to the number of activating and co-stimulatory molecules making up the endodomain. The first-generation CAR constructs only contained an activating domain, namely $\mathrm{CD} 3 \zeta$, whilst the second- and third-generation constructs contain one and two co-stimulatory domains, respectively. In T cells, domains from both the CD28 family (CD28 and ICOS) and the TNF receptor family (4-1BB, OX40, and CD27) have been widely tested, with the FDA-approved CD28- and 4-1BB-containing constructs being most commonly used to date [14-18]. The choice of co-stimulatory domains allows for fine-tuning of the desired $\mathrm{T}$ cell response, whereby CD28-based CARs exhibit an increased cytolytic capacity and shorter persistence compared to 4-1BB-based CARs [19].

\subsection{Limitations of CAR-T Cells}

Successful clinical trials with second-generation autologous CD19-targeted CAR-T cells resulted in FDA approval, with two products, namely Kymriah ${ }^{\circledR}$ (Novartis) and Yescarta ${ }^{\circledR}$ (Kite/Gilead), currently on the market $[14,15]$. The manufacturing time and costs, as well as severe toxicities, associated with CAR-T cell therapies are current limitations for these products [20]. Generating an autologous CAR-T cell product from chemo-refractory patients is severely limited by the quality of T cells obtained, as well as the survival time of the patients themselves, as the manufacturing process takes 2-4 weeks (Figure 2). Additionally, the patients need to be treatment-free for two weeks prior to apheresis to ensure sufficient cell numbers and viability for the manufacturing process [21]. However, the alternative-treatment with an allogeneic CAR-T cell product-always carries the serious risk of inducing graft-versus-host disease (GvHD) [22]. Irrespective of whether the treatment is autologous or allogeneic, serious side effects are commonly observed with CAR-T cell therapy. Neurotoxicity, immune effector cell-associated neurologic syndrome (ICANS), and cytokine release syndrome (CRS) are frequently observed, both of which are serious conditions which can be fatal if not treated, particularly in the case of CRS (Figure 3) [23,24]. It has been shown that 37-93\% of patients receiving CAR-T cell therapy for leukemia or lymphoma develop CRS with symptoms ranging from a high fever to hypotension, hypoxia, and tachycardia, with high-grade CRS requiring intensive care treatment [20,21,25-28]. CRS is the result of on-target CAR-T cell activation leading to massive proliferation and cytokine/chemokine release, with elevated levels of IL-6, IFN $\gamma$, GM-CSF, and soluble IL-6R and IL-2R $\alpha$ being commonly observed. Tocilizumab, which is an anti-IL-6 receptor agonist, is routinely used to counter the high levels of IL-6, 
with corticosteroids being administered in patients not responding to tocilizumab [14,21,26,29-33]. ICANS often develop after CRS, with symptoms ranging from encephalopathy to expressive aphasia and seizures, but rare cases of cerebral edema have also been reported [26,34,35]. Between $23 \%$ and $67 \%$ of patients treated with CAR-T therapy against lymphoma or leukemia develop ICANS [20,21,25-28]. CAR-T cell-induced toxicities usually require three weeks of 'in-patient' treatment.

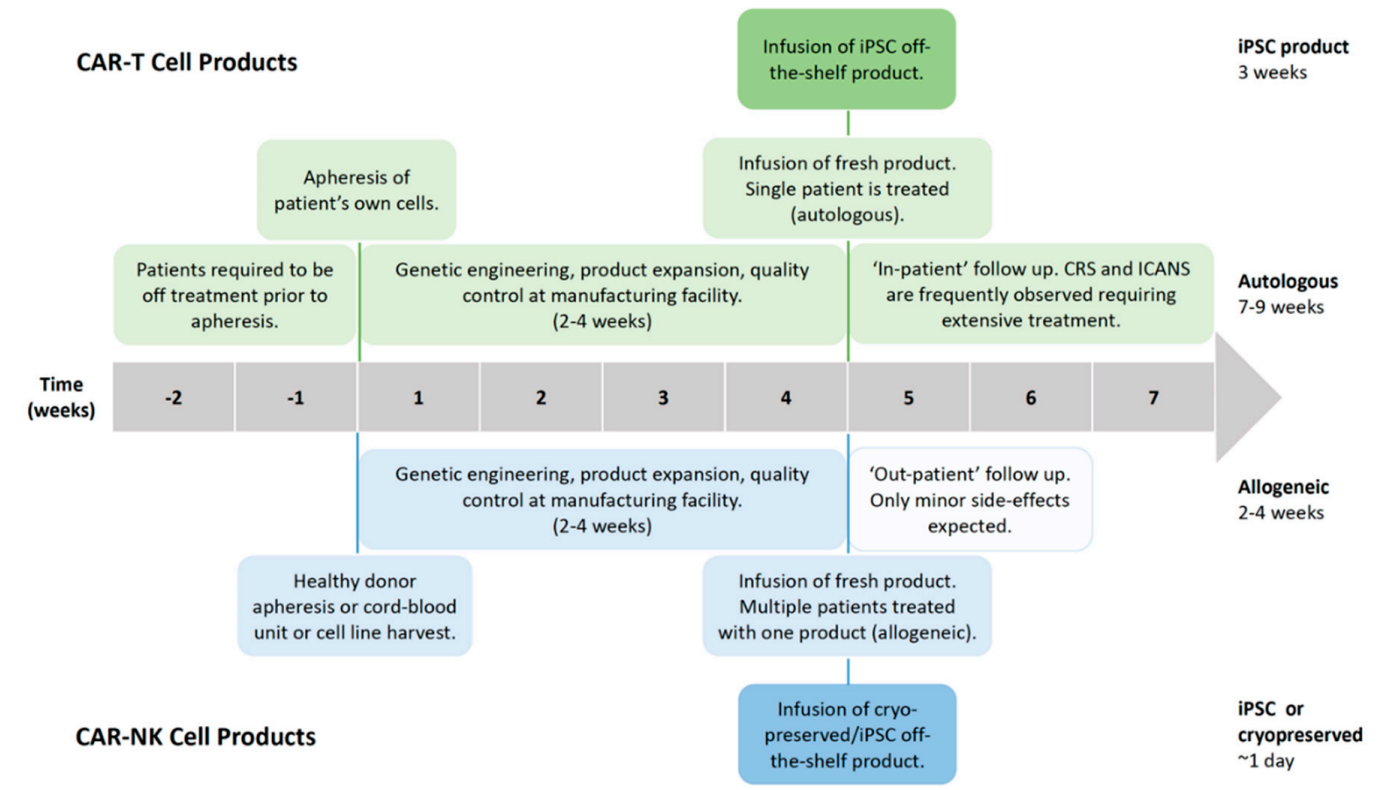

Figure 2. Manufacturing timeline of CAR-T cell and CAR-natural killer (NK) cell products. Comparison of the manufacturing time for CAR-T and CAR-NK cell products, from harnessing the cells for product processing to patient monitoring after treatment. Abbreviations: CRS, cytokine release syndrome; ICANS, immune effector cell-associated neurologic syndrome; iPSC, induced pluripotent stem cell.

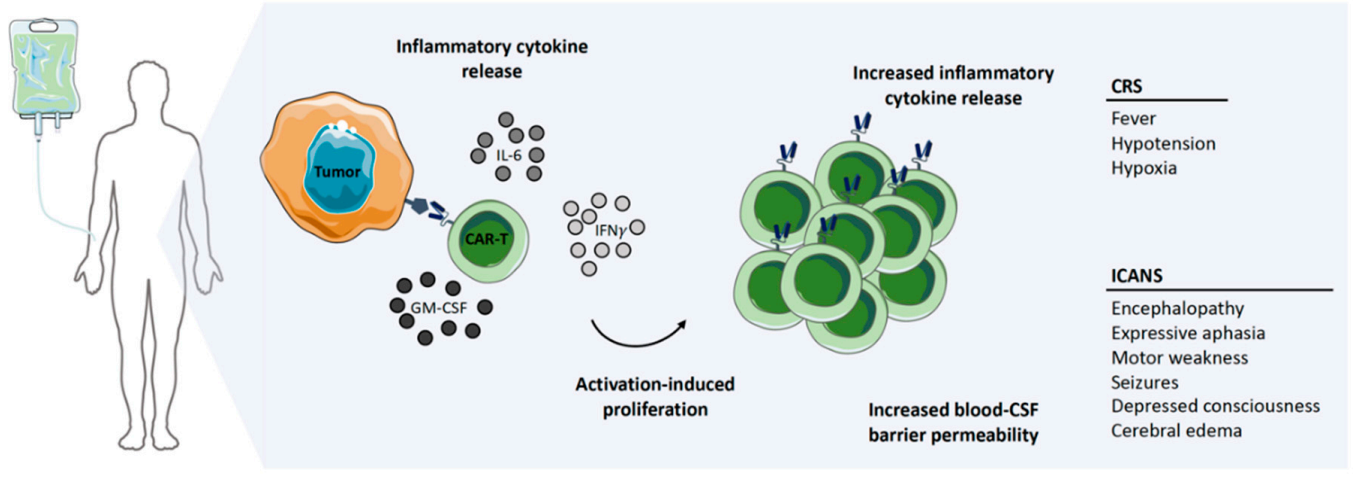

Figure 3. CAR-T cell treatment-related toxicities. Toxicities associated with the antigen-induced activation and proliferation of CAR-T cells caused by the release of cytokines. Abbreviations: IL-6, interleukin-6, IFN $\gamma$, interferon gamma; GM-CSF, granulocyte-macrophage colony-stimulating factor; CSF, cerebrospinal fluid; ICANS, immune effector cell-associated neurologic syndrome; CRS, cytokine release syndrome.

The fourth generation of CAR constructs is focused on addressing the current limitations of CAR-T cell therapy. These next-generation CAR designs can be further classified into subgroups based on their rational (Figure 1b). ON-switch CARs rely on a small molecule to assemble the fragmented CAR construct, allowing for controlled CAR activation through the administration of a drug [36]. Universal CARs are another type of fragmented CAR design, whereby the antigen-specific portion can be exchanged to facilitate the targeting of numerous different cancer types through the same TM and 
intracellular signaling construct [37-40]. OR-gate CARs aim to prevent tumor escape by providing two $\mathrm{scFv}$ domains against different targets, which are either bound to a single TM and intracellular domain (Tandem CAR) or are simply two complete CAR constructs expressed on the same cell (Dual CAR) [41-43]. Signaling through either scFv will activate the T cell. AND-gate CARs, as the name implies, also feature two scFvs, but require the presence of both antigens on the same cell before signal propagation. This approach allows for the targeting of non-tumor specific antigens, as tumor specificity is achieved by the dual expression of both antigens (Combinatorial CAR and synNotch Receptor) [44-46]. T cells redirected for universal cytokine killing (TRUCK)—CAR constructs carrying a transgenic 'payload'are a novel design for targeting solid tumors. These constructs feature the CAR-inducible expression of a transgene product, such as IL-12, facilitating release of the 'payload' at the tumor site to modulate the tumor microenvironment $[47,48]$. Similarly, inhibitory CARs are focused on turning an immunosuppressive signal from a tumor cell into an activating signal by fusing the extracellular inhibitory domain, for example, PD-1, to an activating intracellular CAR domain [49].

Lastly, in an attempt to increase the safety profile of CAR-T cells, a suicide switch that can be triggered upon the development of adverse effects was developed, yet only $\sim 10 \%$ of current clinical trials implement this safety feature [50]. One alternative strategy for mitigating the limitations of CAR-T cell-based therapy is to utilize natural killer (NK) cells instead.

\subsection{Advantages of CAR-NK Cells}

Adoptive cell therapy (ACT) with allogeneic haplo-identical NK cells has been clinically proven to be safe, without the risk of inducing GvHD. NK cells have been shown to be major contributors to the graft-versus-tumor (GvT) response observed after hematopoietic stem cell transplantation (HSCT) for acute myeloid leukemia (AML) [51,52]. Tumor escape via the loss of antigen or via the loss of major histocompatibility complex I (MHC-I) expression renders CAR-T cells helpless in detecting tumor cells [53]. CAR-NK cells, on the other hand, retain their innate cytolytic capacity against germline-encoded tumor/stress ligands and are able to detect MHC-I-negative tumor cells due to their lack of a self-antigen $[11,54]$. Decreased MHC-I expression is a characteristic ascribed to cancer stem cells (CSCs), which, together with the ligand expression of activating receptors, namely NKp30, NKp44, and NKG2D, is believed to sensitize CSCs to cytokine-activated NK cell-mediated killing [55-57]. Shedding of the NKG2D ligands MICA and MICB by breast CSCs and the absence of NKG2D ligands on leukemia stem cells are effective mechanisms utilized by CSCs to evade NK cell detection [58,59]. Furthermore, NK cells have the ability to perform serial killing and although generally short-lived, cytomegalovarius (CMV)-induced memory-like adaptive NK cells have been shown to be long-lived and highly potent [60]. The safety profile of NK cells, combined with their anti-tumor potential, makes them a promising cell type for the implementation of CAR technology, which can redirect their cytotoxic potential towards a specific target. The feasibility of manufacturing an off-the-shelf CAR-NK cell product to universally treat patients would significantly increase the speed of administration, effectively reducing the lag time from the decision to treat and first dosing to 1 day (Figure 2). As no severe toxicities are observed or expected with CAR-NK cells, treatment can be administered with 'out-patient' follow-up monitoring, significantly reducing the huge indirect costs associated with CAR-T cell therapy due to lengthy post-treatment hospitalization [61]. While an induced pluripotent stem cell (iPSC)-derived CAR-T cell product can also be manufactured as an off-the-shelf product, extra genetic modification is required to remove the endogenous TCR in order to produce a universal product without the need for HLA-matching. Nonetheless, the serious side effects observed from CAR-T cell therapy would not be eliminated through the use of iPSC-derived CAR-T cells, retaining the need for post-treatment hospitalization.

A recent meta-analysis of ongoing clinical trials across the globe identified 520 active trials examining a total of 64 different CARs, with $96.4 \%$ of trials using CAR-T cells [50]. Hence, the CAR-NK cell field is still in its infancy in terms of translating laboratory studies into a clinical setting at present. 


\section{Evolution of the CAR-NK Field}

Unlike T cells, NK cells do not express antigen-specific surface receptors to discriminate malignant cells. Instead, a large repertoire of germline-encoded inhibitory and activating receptors provides the cell with the necessary information to distinguish a healthy cell from a foreign, infected, or transformed cell. It is the balance of signals received, as well as the absence of important inhibitory signals, termed 'missing self', that modulate the release of cytotoxic granules for target elimination [54]. Within the blood, cytotoxic CD56 ${ }^{\text {dim }} \mathrm{NK}$ cells and immunomodulatory CD56 $6^{\text {bright }} \mathrm{NK}$ cells make up the two main populations of NK cells. In reality, it has been estimated that up to $10^{5}$ subsets of NK cells exist based on the vast repertoire of surface receptor expression [62,63]. Compared to T cells, NK cells are fairly resistant to genetic engineering and more difficult to expand to the large numbers needed for infusion, as the number of cell divisions they can undergo is limited. To mitigate these challenges, many early CAR-NK cell studies have been performed with NK cell lines instead of primary NK cells obtained from umbilical cords or peripheral blood (Figure 4) [64,65].

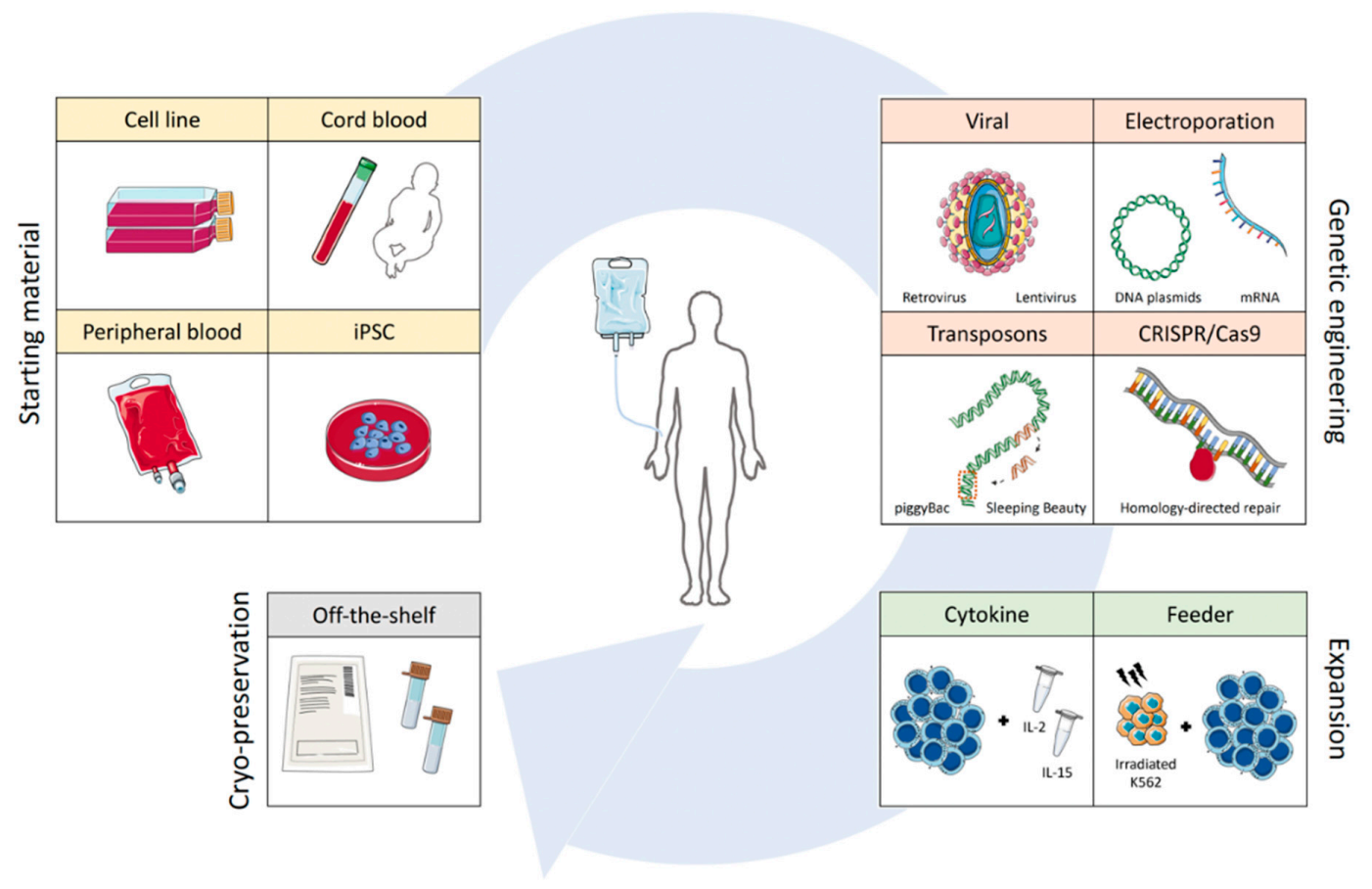

Figure 4. Overview of the CAR-NK cell manufacturing process. The four manufacturing stages of CAR-NK cell production, from the choice of starting material to genetic modification, product expansion, and the subsequent cryopreservation of treatment doses. Abbreviations: iPSC, induced pluripotent stem cell; CRISPR, clustered regulatory interspaced short palindromic repeats; IL-2, interleukin-2; IL-15, interleukin-15.

\subsection{NK Cell Line (NK-92)}

The majority of CAR-NK cell studies to date have been performed with NK-92 cells, including a large number of current clinical trials (Table 1) [50]. Although NK-92 cells phenotypically resemble the immunomodulatory and poorly cytotoxic CD56 bright population found in the blood, they are functionally highly cytotoxic [66-68]. Their activating receptor repertoire includes NKp30, NKp46, and NKG2D, and their inhibitory repertoire is limited to ILT-2, NKG2A, and KIR2DL4 at low levels [66,68]. The lack of inhibitory killer immunoglobulin-like receptor (KIR) expression on the cell surface and inability to kill through antibody-dependent cellular cytotoxicity (ADCC) due to low or absent CD16 expression greatly differentiates this cell line from primary NK cells. These deficiencies have led to NK-92 cells being genetically engineered to express a high-affinity CD16 receptor, with the rational of 
combining CD16-expressing NK-92 cells together with anti-tumor monoclonal antibodies to facilitate tumor elimination via ADCC [69]. Furthermore, numerous studies have overserved increased IFN $\gamma$ release in CAR-expressing NK-92 cells compared to relatively low production in unmodified NK-92 cells in response to target exposure [70-75].

Developing a cell-line-based CAR product brings the advantage of an unlimited proliferative capacity and reduced sensitivity to repeated freeze/thaw cycles. These properties allow for the manufacturing of a universal off-the-shelf product, severely reducing both the manufacturing time and cost. Conversely, a cell-line-based product raises new questions of safety, as NK-92 cells are both Epstein-Barr virus (EBV)-positive and derived from an NK lymphoma. Therefore, NK-92 cells carry many genetic abnormalities and have the potential to permanently engraft upon infusion, making irradiation prior to infusion an absolute necessity [76]. Numerous studies have demonstrated that NK-92 cells retain their cytotoxicity post-irradiation, but the lack of in vivo proliferation results in clearance of the infused cells after only 7 days [74,77-80]. Treatment with an NK-92-based CAR product will therefore most likely require multiple rounds of infusion [78].

Recently, NK-92 cells were engineered to express a fourth-generation CAR construct originally designed for $\mathrm{T}$ cells, termed UniCAR [81]. This CAR platform combines both the universal aspect and the ON-switch design. The two-component platform consists of a CAR construct against the E5B9 epitope, which is not expressed ectopically, and a bi-specific target molecule, namely the E5B9 epitope fused to a tumor-specific scFv. The target molecule provides tumor specificity and can be exchanged to facilitate the targeting of different tumor types. Importantly, the CAR construct is only active in the presence of the target molecule which is individually administered, and due to its limited half-life, functions as an off-on switch. By implementing this CAR design in NK-92 cells, the resulting product is not only universal and inducible, but furthermore, can be manufactured as an off-the-shelf product [81].

\subsection{Cord Blood NK Cells}

NK cells isolated from cord blood (CB) present another possible starting material for a CAR-NK product [82]. Between $15 \%$ and $30 \%$ of CB lymphocytes are NK cells, and although contradictory reports have been published, they are generally considered to be more naïve in phenotype and function compared to peripheral blood (PB) NK cells. Reduced expressions of CD16, granzyme B, perforin, and KIRs have been reported, as well as a decreased expression of cell adhesion molecules, including CD2, CD11a, CD18, and CD62L. Limited ADCC potential and limited functional maturation through KIR expression, together with a reduction in adhesion molecules, all contribute to the reduced cytotoxic capacity observed in this population of cells [83-86]. A higher percentage of CB NK cells are CD56 bright, contributing to the overall higher expression of the inhibitory receptor NKG2A, the ligand for which, HLA-E, is commonly upregulated on tumor cells and is associated with a poor outcome [87]. Therefore, NKG2A is an important inhibitory checkpoint which has been targeted with monoclonal antibody therapy to unleash NK cell potential in the setting of head and neck squamous cell carcinoma [88]. In line with their immature nature, CB NK cells have a higher proliferative capacity and are very receptive to cytokine stimulation. While umbilical cord blood banks make CB-derived NK cells a feasible starting product, the small volume obtained from cord blood requires the NK cells to undergo a large number of cell divisions before obtaining sufficient cell numbers required for infusion [83]. Nonetheless, clinical CAR-NK cell products have been manufactured from CB NK cells and are currently being tested in the clinic [89].

\subsection{Peripheral Blood NK Cells}

Approximately $90 \%$ of peripheral blood NK cells are cytotoxic CD56 ${ }^{\mathrm{dim}} \mathrm{NK}$ cells, expressing a vast repertoire of inhibitory and activating receptors. Compared to CB NK cells, PB NK cells are more mature, resulting in an increased functionality, but reduced proliferative capacity [90]. Their safety as an adoptive cell therapy product has been proven through numerous clinical trials, in both 
an autologous and allogeneic setting, with NK cells from matched and HLA-mismatched, as well as matched and KIR-ligand mismatched, donors [51,91-93]. The possibility of using cells from an unrelated HLA-mismatched donor substantially increases the number of possible donors to choose from, and therefore, can significantly increase the quality of the final product. Apheresis, a method by which nucleated cells are extracted from the blood of healthy donors, facilitates the isolation of a sufficient number of NK cells, often via CD3 and CD19 depletion, which are then often further expanded and primed by cytokines, such as IL-2 or IL-15, prior to infusion. Cytokine-based and feeder-based expansion protocols will be discussed in Sections 3.5 and 3.6, respectively. While clinical results have been promising against hematopoietic malignancies, largely AML, the clinical response has been patient-specific and difficult to predict based on pre-clinical in vitro studies.

\section{4. iPSC-Derived NK Cells}

A fourth, and fairly recent, source of NK cells is iPSC-derived NK (iNK) cells [94]. iPSC-derived NK cells are an ideal source for an off-the-shelf CAR-NK cell product due to their unlimited proliferative potential [95]. Comparatively, the transduction efficiency plays an important role in manufacturing CB or PB-derived CAR-NK cells, and only a single CAR-transduced iPSC cell is needed to generate a universal off-the-shelf CAR-NK cell product. However, iPSC-derived NK cells are still in their infancy and a number of challenges still need to be overcome to generate the ideal off-the-shelf product. iPSCs are commonly derived from non-hematopoietic cells, such as fibroblasts, yielding iNK cells with an immature phenotype characterized by low CD16 expression, high NKG2A expression, and lower KIR expression compared to PB NK cells [94,96,97]. This raises the question of how their cytolytic potential is maintained and released upon target cell encounter, which could be addressed through the expression of a CAR construct. Similar to NK-92 cells, genetically engineering iNK cells to express lacking surface proteins, such as CD16, is a potential solution to this current limitation. Although their proliferative capacity is unmatched, the question of persistence upon infusion remains and needs to be addressed before the true potential of iPSC-derived NK cells can be harnessed [75]. The first iPSC-derived CAR-NK cell product, FT596, expresses a CD19-CAR construct and a high-affinity, non-cleavable CD16 Fc receptor plus an IL-15 receptor fusion protein and will be used in combination with CD20-directed monoclonal antibody therapy. This product therefore addresses not only the limited persistence, but also the low CD16 expression of iNK cells and puts combination immunotherapy to the test. Promising preclinical results from in vivo studies in humanized mice with CD19+ lymphoma have paved the way for a recently listed Phase I clinical trial (NCT04245722).

\section{Unique Challenges of CAR-NK Cells}

The successful implementation of CAR-NK cells as a therapeutic cancer treatment is currently hampered by three main factors, namely, (1) the resistance of NK cells to genetic engineering, (2) the limited proliferative potential of NK cells, and (3) their limited persistence upon infusion.

\subsection{Viral Transduction}

Historically, the viral transduction of primary NK cells with either retrovirus or lentivirus has had poor efficiency [98]. Gamma-retroviral-based vectors require cells to be actively proliferating to gain entry into the cell [99]. Lentiviral-based vectors can infect both cycling and non-cycling cells and carry larger transgenes, but are also limited in their efficiency in primary NK cells as viability is often negatively affected [100]. In order to improve the transduction efficiency of largely virally-resistant NK cells, polybrene, which is a cationic polymer that facilitates viral entry, is commonly used [101]. Another alternative is Retronectin-a truncated version of fibronectin-which works by colocalizing with the virus at the cell's surface [102,103]. Vectofusin-1, which is a short cationic peptide that functions as a strong transduction enhancer, was originally discovered to greatly enhance the lentiviral transduction of hematopoietic stem cells and has since been adopted in the NK cell field [104]. 
Optimization of the virus packaging identified a higher transduction efficiency for primary NK cells when a Baboon envelope pseudotyped lentivirus (BaEV-LV) was used [105]. The previous standard was vesicular stomatitis virus GP (VSV-G) [106]. BaEV-LV utilizes both ASCT1 and ASCT2 (sodium-dependent neutral amino acid receptors), which are highly expressed on hematopoietic cells, to obtain entry into the cell. The transduction efficiency was also increased when NK cells were previously activated with cytokines prior to transduction, likely as a result of the cytokine-induced proliferation facilitating viral uptake $[107,108]$.

\subsection{Electroporation}

One non-viral strategy for genetically engineering NK cells is through the electroporation of DNA or mRNA plasmids. The electroporation of DNA has a low efficiency, but with prior activation of the NK cells combined with mRNA-based plasmids, electroporation efficiencies ranging from $80 \%$ to $90 \%$ have been achieved in primary NK cells $[98,109]$. The drawback of using electroporation to obtain CAR expression is the transient expression that results, as no stable integration of the construct in the DNA is possible. The surface expression of CAR constructs on primary NK cells can range from as little as 3-5 days before expression is lost, greatly reducing the therapeutic time window [11,109-111]. Electroporation is therefore not a feasible method for genetically engineering a stable CAR-NK cell product.

\subsection{Transposons}

One alternative for non-viral transduction that is currently being investigated is the use of transposons. DNA transposons are mobile units of DNA, often referred to as 'jumping genes', which occur naturally in many organisms. Their ability to randomly integrate throughout the genome makes them an extremely attractive method since viral transduction is often biased towards transcriptionally-active and highly-expressed genes, resulting in their disruption [112]. Two main methods-piggyBac and the sleeping beauty (SB) transposon system-are most commonly used, with an SB-based CAR vector currently being tested in the clinic [75]. SB is originally derived from fish, but retains its activity in the human genome [113]. It consists of two components: the SB transposase mediating the cutting-and-pasting and the DNA vector flanked by terminal inverted repeats (TIRs) to which the transposase can bind to mediate its near random integration into the genome [114]. Genes $>100 \mathrm{~kb}$ in length can be transduced with this method, making it an attractive higher efficiency option for CAR integration [115].

However, entry of the SB transposase and gene vector into the cell still needs to be facilitated, either through electroporation or viral infection. One method is to use a hybrid adenovirus/transposon vector together with the hyperactive SB100X transposase, which facilitates entry via the adenovirus (non-integrating virus) and DNA integration via the transposase [112]. Another alternative approach is to introduce minicircles containing the gene vector along with transposase mRNA via electroporation [116]. Minicircles are DNA plasmids devoid of the bacterial backbone, which have been shown to have a higher integration efficiency compared to traditional plasmids. The advantage of using transposase mRNA over DNA is the short half-life upon transfer. DNA transposons have the ability to integrate into DNA, but are not stable and have the potential to relocate in the presence of transposases. In order to achieve stable integration, it is advantageous to retain transposase expression for a limited timeframe, allowing for vector integration, but preventing further re-mobilization at a later time point. Furthermore, it eliminates the possibility of the highly-active transposases permanently integrating themselves.

Apart from the potential re-mobilization of integrated vectors, another limitation to using transposons for CAR transduction is that numerous copies of the CAR construct are introduced per cell. Plasmid-based strategies often result in 8-20 insertions per cell, while a new soluble form of SB transposase produced resulted in only 2-12 insertions per cell [117]. This can lead to excessive activation and potential for NK cell exhaustion, similar to AICD observed in T cells. Nonetheless, 
transposon-engineered CAR-NK cells are a promising alternative for achieving stable expression without viral integration.

\subsection{CRISPR/Cas9}

Previously discussed transduction methods have relied on vector integration without specifying the site of integration. The potential for the integration and subsequent disruption of essential survival genes or tumor suppressor genes can be detrimental and dangerous for a clinical product [118]. The discovery of the CRISPR/Cas9 system opened the possibility of targeted gene integration with a high efficiency, compared to similar methods, such as transcription activator-like effector nucleases (TALENs) or zinc-fingers nucleases (ZFNs) [119]. CRISPR/Cas9 utilizes guide RNAs to direct the Cas9 nuclease to the gene of interest to introduce double-stranded breaks. Through homologous directed repair (HDR), a gene vector can be incorporated, providing an efficient method of gene-insertion at a targeted location. CRISPR technology has been used to knock-out the endogenous TCR locus in T cells and replace it with the CAR construct to generate allogeneic universal CAR-T cells [118,120]. In NK cells, targeted CAR insertion combined with gene knock-out opens up new possibilities for improving primary CAR-NK cell products. Targeting key transcription factors involved in NK cell exhaustion, terminal differentiation, and clonal expansion, as observed in adaptive NK cells, and regulators of cell cycle progression and apoptosis, could help in identifying the ideal CAR-NK cell product.

\subsection{Cytokine-Based Expansion}

Cytokine-based expansion protocols often rely on supra-physiological levels to induce the expansion of primary NK cells. Various combinations of IL-2, IL-12, IL-15, IL-18, and IL-21 have been tested, with the aim of either obtaining maximum cell numbers or tuning the phenotypic profile by expanding a particular subset of NK cells [121]. By combining IL-15 with IL-12 and IL-18, cytokine-induced memory-like NK cells have been generated from mouse and human NK cells, which exhibited an increased anti-tumor response and persistence [122-127]. Immature NK cell subsets are most receptive to cytokine input and also possess the highest proliferative capacity, while mature NK cell subsets favor a receptor-mediated input and have a reduced proliferative capacity [90]. High doses of cytokines therefore result in a skewing of the NK cell population towards a more naïve phenotype, but also increase the transcription of effector molecules, including granzyme B and perforin [128]. Expansion protocols solely relying on a cytokine input have a finite fold expansion and often induce cytokine-dependence in the expanded cells. The addiction to supra-physiological levels is a major concern for adoptive cell therapy as the cells undergo massive cytokine-withdrawal upon infusion, severely limiting their in vivo persistence and thus the therapeutic window [129]. The in vitro expansion of primary NK cells with IL-15 has been shown to result in dose-dependent cytokine addiction, which correlated with the degree of proliferation. These cytokine-addicted NK cells were highly susceptible to the induction of apoptosis upon IL-15 withdrawal and this was associated with an altered expression of BCL-2 and BIM-the main anti/pro-apoptotic molecules in cycling NK cells [129]. Cytokine-addiction therefore needs to be considered when infusing an expanded primary NK cell product, with one possible strategy being a gradual reduction in the cytokine concentration prior to infusion.

\subsection{Feeder-Based Expansion}

Feeder-based expansion protocols combine the receptor-mediated input from the feeder system with cytokine support, to facilitate the large-scale expansion of primary NK cells [121]. A number of different feeder systems have been used, including EBV-transformed lymphoblastoid cell lines (LCLs), autologous peripheral blood mononuclear cells (PBMCs), and various NK cell-sensitive cell lines, such as 721.221 and K562 [130-132]. In order to prevent feeder cell outgrowth and facilitate NK cell expansion, feeder cells are irradiated prior to co-culture, effectively preventing further cell division. Elimination of the feeder cells by the NK cells usually occurs within 1-2 weeks, making 
this a feasible system for clinical application [133]. Compared to cytokine-only-based expansion protocols, feeder-based systems yield higher total fold expansion at lower cytokine doses, making this an attractive expansion method for CAR-based NK cell therapy [121]. Additionally, the lower cytokine doses required for expansion with feeder cells could help mitigate the cytokine withdrawal-induced apoptosis upon infusion.

Genetically engineered feeder cells expressing specific surface ligands to aid in NK cell expansion have been developed. These include membrane-bound cytokines, such as IL-15, IL-18, and IL-21, as well as ligands to activating receptors expressed on NK cells, such as 4-1BBL, HLA-E, and OX40L [132,134-136]. While HLA-E-expressing-modified 721.221 cells (721.221-AEH) have been used as a method to preferentially expand adaptive $\mathrm{NKG}_{2} \mathrm{C}^{+} \mathrm{CD} 56^{\mathrm{dim}} \mathrm{NK}$ cells from a bulk NK cell population, 4-1BBL-expressing K562 cells have been used to generally increase NK cell expansion and increase the viability [132,136,137]. Combining K562-4-1BBL with IL-15 and IL-21 support has resulted in superior expansion, reaching up to a $10^{5}$ fold expansion in 4 weeks, which has been attributed to the IL-21-induced increase in telomere length, prolonging the proliferative capacity of NK cells [137]. Furthermore, the activation of both STAT5 and STAT3 appears to be beneficial in proliferating NK cells. The mechanism by which signaling through $4-1 \mathrm{BB}$ augments proliferation still remains to be deciphered.

\subsection{In-Vivo Persistence}

Evidence from clinical trials of adoptive cell therapy often fails to detect the presence of infused NK cells more than 1-2 weeks after infusion [91,127,138]. While the short life-span of NK cells contributes to their safety profile in the setting of $\mathrm{ACT}$, it also significantly narrows the therapeutic window, preventing any long-term surveillance by the infused cells. One option for extending the therapeutic window is to give systemic cytokine support to induce proliferation of the infused product in vivo. Although IL-2 and IL-15 have been tested in clinical trials, both are associated with severe side effects [139]. Fever, chills, myalgias, and capillary leak syndrome have been observed after systemic IL-2 treatment, which also has the unwanted side effect of supporting regulatory $\mathrm{T}$ cell $\left(\mathrm{T}_{\text {reg }}\right)$ expansion [140]. IL-15 does not promote the expansion of any unwanted bystander populations, but has been shown to cause neutropenia when given systemically [141]. Furthermore, systemic IL-15 treatment only induced NK cell expansion for the duration of the treatment, effectively eliminating it as a method for inducing long-term persistence [142]. While optimizing the persistence of CAR-NK cells has definite room for improvement, long-term persistence as observed with CAR-T cells is unlikely. In line with the ACT of activated NK cells, CAR-NK cell therapy has great potential as a bridging therapy for patients with refractory and relapsing malignancies.

\section{NK-Specific CAR Constructs}

Implementation of the CAR technology in NK cells is often performed with constructs optimized for inducing $\mathrm{T}$ cell activation. Although some of the signaling is conserved between $\mathrm{T}$ cells and NK cells, namely CD3 $\zeta$ and 4-1BB, other co-stimulatory domains commonly used in CAR-T cells, as well as TM domains and hinges, are completely absent in NK cells, namely CD8 $\alpha$ and CD28 $[61,143]$. Furthermore, differences in activating signaling, leading to immune synapse formation and subsequent cytolysis of the target cell, are cell type-specific. This is further complicated by the fact that the most potent NK cell subset, the so called 'serial-killers', still cannot be identified phenotypically. Here, we will focus on reviewing only NK-specific CAR constructs and the associated signaling in NK cells.

Activating receptors on NK cells utilize a variety of adapter molecules for downstream signaling, including $\mathrm{CD} 3 \zeta$, DAP10, DAP12, and FcR $\gamma$ chains. While $\mathrm{CD} 3 \zeta$ contains and signals via 3 immunoreceptor tyrosine-based activation motif (ITAM) domains, DAP10, DAP12, and FcR $\gamma$ chains only contain one ITAM domain each. NK cell receptors signaling via CD3 include CD16, NKp30, and NKp46, whereby CD16 and NKp46 also signal via FcR $\gamma$ chains. DAP10 is involved in mediating 
signaling through NKG2D compared to DAP12, which functions as the adapter protein for activating KIRs, NKG2C, and NKp44 [144].

NK-specific CAR constructs have largely focused on incorporating either DAP10 or DAP12 as the activating domain or as a co-stimulatory domain alongside CD3 been successful, but only in combination with NKG2D, in line with endogenous NKG2D signaling. A second-generation CAR construct featuring NGK2D as the ectodomain, with DAP10 and CD3C making up the endodomain, exhibited increased surface expression and functionality in primary NK cells tested in vitro and in vivo using an osteosarcoma xenograft mouse model [108]. However, another CAR construct against PD-1 utilizing an NKG2D TM domain fused to 4-1BB and DAP10 found DAP10 to be superfluous, with the same construct lacking DAP10 showing better NK cell functionality [73]. This inhibitory CAR construct aimed to use inhibitory PD-1 signaling to activate the NK cell, utilizing NKG2D only as the TM domain. As a type II protein, NKG2D differs in its transmembrane region when compared to type I membrane proteins that are normally used in CAR constructs, namely CD $8 \alpha$ and CD28. The added challenge of using a type II protein for the TM domain was made evident by the poor surface expression of the constructs [73]. Furthermore, ensuring interaction between NKG2D and DAP10 within the constructs appears to be a main factor in determining effective signaling through DAP10 containing-constructs. This was affirmed by another study comparing a CD19-targeting first-generation CAR containing either DAP10 or CD3 , where $\mathrm{CD} 3 \zeta$ outperformed DAP10 as the activating domain [145]. DAP12, on the other hand, outperformed CD3 $\zeta$ in first-generation CARs transduced into primary NK cells in both in vitro and in vivo mouse studies, regardless of which scFv was used $[109,146]$.

The largest comparison of NK-specific CAR constructs was performed in NK-92 cells, and included an evaluation of four different transmembrane domains (CD16, NKp44, NKp46, and NKG2D) and four different co-stimulatory domains (2B4, DAP10, DAP12, and CD137) in various combinations with $\mathrm{CD} 3 \zeta$ [75]. Only three constructs resulted in an increased cytolytic response, with the construct containing an NKG2D TM domain and 2B4 co-stimulatory domain being chosen for further analysis in iNK cells. Another comparison of 2B4 versus 4-1BB as co-stimulatory domains in NK-92 cells favored the 2B4 containing CAR construct, which induced rapid proliferation, increased cytokine production and degranulation, and decreased apoptosis in the transduced cells [70]. 2B4 is a member of the signaling lymphocytic activation molecule (SLAM)-family receptors and binds CD48, commonly expressed by hematopoietic cells. It signals through its immunoreceptor tyrosine-based switch motif (ITSM), which, upon phosphorylation, recruits adaptor proteins, such as SAP and EAT-2 [147].

To address the issue of short in vivo persistence normally associated with infused NK cells, Liu et al. engineered CB-derived NK cells to express IL-15 [148]. The CAR-transduced cells therefore produced their own soluble IL-15, which was sufficient for sustaining autonomous growth over a period of 42 days. However, the infusion of high doses of CAR-expressing CB-derived NK cells into mice (Raji xenograft model) proved fatal in four mice, due to cytokine release syndrome. Pre-empting the possibility of this lethal side effect, the authors also included an inducible suicide gene as a safety measure. While systemic cytokine support upon NK cell infusion is unfavorable due to the side effects of both IL-2 and IL-15, engineering cells to secrete cytokines does not appear to be a simple solution either.

\subsection{Clinical Trials of CAR-NK Cells}

Clinicaltrials.gov currently has six CAR-NK cell trials listed as actively recruiting and six early Phase I clinical trials that are not yet actively recruiting (Table 1). While many trials are focusing on lymphoma and leukemia, others are targeting solid tumors, including ovarian, prostate, brain, liver, lung, and pancreatic cancer. 
Table 1. Current clinical trials of CAR-NK cells. Clinical trials featuring CAR-NK cells against various target antigens and diseases which are currently actively recruiting or are scheduled to begin recruiting in the near future. Data was obtained from clinicaltrials.gov. Abbreviations: iPSC, induced pluripotent stem cell.

\begin{tabular}{|c|c|c|c|c|c|c|}
\hline Identifier & Status & Disease & Target & Source & Location/Sponsor & Phase \\
\hline NCT03415100 & Recruiting & Metastatic Solid Tumours & NKG2D ligands & PB NK cells & $\begin{array}{l}\text { Third Affiliated Hospital of } \\
\text { Guangzhou Medical University, } \\
\text { Guangzhou, Guangdong, China }\end{array}$ & Phase I \\
\hline NCT03940820 & Recruiting & ROBO1+ Solid Tumors & ROBO1 & NK-92 & $\begin{array}{l}\text { Suzhou Hospital Affiliated to } \\
\text { Nanjing Medical University, } \\
\text { Suzhou, Jiangsu, China }\end{array}$ & Phase I/II \\
\hline NCT03940833 & Recruiting & Multiple Myeloma & BCMA & NK-92 & $\begin{array}{c}\text { Wuxi People's Hospital, Wuxi, } \\
\text { Jiangsu, China }\end{array}$ & Phase I/II \\
\hline NCT03941457 & Recruiting & ROBO1+ Pancreatic Cancer & ROBO1 & NK-92 & $\begin{array}{c}\text { Shanghai Ruijin Hospital, } \\
\text { Shanghai, China }\end{array}$ & Phase I/II \\
\hline NCT03056339 & Recruiting & $\begin{array}{l}\text { B-Lymphoid Malignancies, } \\
\text { Acute Lymphocytic } \\
\text { Leukemia, Chronic } \\
\text { Lymphocytic Leukemia, } \\
\text { Non-Hodgkin Lymphoma }\end{array}$ & CD19 & CB NK cells & $\begin{array}{c}\text { University of Texas MD Anderson } \\
\text { Cancer Center, Houston, Texas, } \\
\text { United States }\end{array}$ & Phase I/II \\
\hline NCT03383978 & Recruiting & HER2+ Glioblastoma & HER2 & NK-92 & $\begin{array}{l}\text { Johann W. Goethe University } \\
\text { Hospital, Frankfurt, Germany }\end{array}$ & Phase I \\
\hline NCT03692767 & Not yet recruiting & $\begin{array}{l}\text { Refractory B-Cell } \\
\text { Lymphoma }\end{array}$ & CD22 & Unknown & $\begin{array}{l}\text { Allife Medical Science and } \\
\text { Technology, Beijing, China }\end{array}$ & Early Phase I \\
\hline NCT03690310 & Not yet recruiting & $\begin{array}{l}\text { Refractory B-Cell } \\
\text { Lymphoma }\end{array}$ & CD19 & Unknown & $\begin{array}{l}\text { Allife Medical Science and } \\
\text { Technology, Beijing, China }\end{array}$ & Early Phase I \\
\hline NCT03692637 & Not yet recruiting & Epithelial Ovarian Cancer & Mesothelin & PB NK cells & $\begin{array}{l}\text { Allife Medical Science and } \\
\text { Technology, Beijing, China }\end{array}$ & Early Phase I \\
\hline NCT03692663 & Not yet recruiting & $\begin{array}{l}\text { Castration-resistant } \\
\text { Prostate Cancer }\end{array}$ & PSMA & Unknown & $\begin{array}{l}\text { Allife Medical Science and } \\
\text { Technology, Beijing, China }\end{array}$ & Early Phase I \\
\hline NCT03824964 & Not yet recruiting & $\begin{array}{l}\text { Refractory B-Cell } \\
\text { Lymphoma }\end{array}$ & CD19/CD22 & Unknown & $\begin{array}{c}\text { Beijing Cancer Hospital, Beijing, } \\
\text { China }\end{array}$ & Early Phase I \\
\hline NCT04245722 & Not yet recruiting & $\begin{array}{l}\text { B-Cell Lymphoma, Chronic } \\
\text { Lymphocytic Leukemia }\end{array}$ & CD19 & iPSC & Fate Therapeutics, San Diego, USA & Phase I \\
\hline
\end{tabular}


Results from small-scale clinical trials $(n=3)$ with both NK-92 and primary CAR-NK cells targeting CD33 or NKG2D ligands have been reported $[109,149]$, but the first large-scale Phase I/II clinical trial was only recently published in February 2020 [89]. Eleven patients with either relapsed or refractory chronic lymphocytic leukemia (CLL) or non-Hodgkin's lymphoma received an allogeneic CB-derived CAR-NK cell product after undergoing a standard lymphodepleting treatment of cyclophosphamide/fludarabin. Although donor NK cells were originally chosen based on a partial HLA-match (4/6), the absence of GvHD resulted in donor criteria focusing on KIR-ligand mismatch instead, with no regard given to HLA-matching for the final two patients. Unfortunately, the number of donors receiving a KIR-ligand mismatched product was too low (5/11) to draw any conclusions. Eliminating the need for HLA-matching highlights the possibility of generating a truly off-the-shelf product, although the viability and potency of the product after a freeze/thaw cycle still need to be clinically tested. The short manufacturing time of the CAR product enabled each patient to receive an individually manufactured clinical product within 2 weeks of enrollment into the clinical study. Eight out of the 11 patients responded to the treatment, with seven patients achieving complete remission. The high response rate and absence of serious side effects, such as CRS, GvHD, and neurotoxicity, proved the feasibility and efficacy of CAR-NK cells as promising new cancer immunotherapy.

Compared to the previously published in vitro study, where increased levels of IL-15 were detected in the supernatant of the IL-15-producing CAR-NK cells sustaining autonomous cell growth, serum levels of IL-15 in treated patients did not exceed baseline levels $[89,148]$. The detection of CAR-NK cells in circulation by flow cytometry was limited to the first 14 days and highly variable among donors. Quantitative PCR was used for long-term detection of the vector transgene, although this only correlated with the treatment dose received for the first 14 days. While the durability of the CAR-NK cell therapy could not be assessed, as remission consolidation therapy was allowed after the initial 30 days, patients that responded to the therapy exhibited a significantly higher early expansion of CAR-NK cells. Considering the severity of disease and multiple rounds of failed chemotherapy (3-11) these patients had previously undergone, a response rate of 8 out of 11 patients is a tremendous success.

\subsection{Endogenous Signaling in CAR-NK Cells}

Inhibitory receptor ligation by self MHC-I molecules fine-tunes the functional potential of an NK cell through modulation of the lysosomal compartment, leading to granzyme B retention in cytotoxic granules [150]. Educated NK cells, having received an inhibitory receptor input from cognate ligands, exhibit an increased functional potential upon receiving an adequate activating receptor input compared to uneducated NK cells. The main inhibitory receptors educating naïve NK cells are NKG2A and KIRs. NKG2A-mediated inhibition is eventually replaced by the stronger KIR-mediated inhibition during maturation [151]. Oei et al. have addressed the question of whether or not CAR signaling was strong enough to overcome the endogenous inhibitory signaling [11]. Indeed, CAR-expressing NKG2A ${ }^{+}$ NK cells were able to overcome HLA-E mediated inhibition and effectively lyse 721.221-AEH cells. However, this was not the case for KIR-mediated inhibition, whereby cognate self-ligand expression on tumor cells dampened the cytolytic response of CAR-expressing NK cells. While CAR expression increased the functional response to antigen-expressing targets cells, the functional hierarchy between educated and uneducated cells was maintained [11]. Hence, the selection of a functional NK cell starting population is highly advantageous for maximizing the anti-tumor effect.

\section{Perspective on the Future of CAR-NK Cells}

The success of CAR-T cell therapy against CD19-expressing lymphomas in the clinic has facilitated rapid progression in the CAR-NK cell field. FDA approval of the first genetically modified cell product has paved the way to the clinic for CAR-NK cells, but simply incorporating constructs optimized for T cells into NK cells is suboptimal. The biological and molecular mechanisms leading to cellular activation greatly differ between $\mathrm{T}$ and $\mathrm{NK}$ cells and thus need to be considered when designing a CAR-NK cell construct. Combination therapy of CD16-expressing CAR-NK cells together with monoclonal 
antibody therapy is one possibility for utilizing the full cytotoxic potential of NK cells through both target-specific lysis and ADCC. The challenges of genetically engineering primary NK cells has resulted in many studies and clinical trials being performed with NK-92 cells. The development of new methods and optimization of existing technologies will facilitate more efficient genetic engineering of primary NK cells, allowing primary NK cells to replace the largely NK-92 CAR products currently being tested in the clinic.

Lastly, if the problem of persistence can be addressed, either through additional engineering of the construct or by furthering our understanding of the requirements for sustained NK cell proliferation, CAR-NK therapy will have great potential as a new immunotherapy against cancer.

Funding: This research received no external funding.

Acknowledgments: The authors would like to thank Servier Medical Art for providing free medical images, which were adapted for the figures included in this article.

Conflicts of Interest: N.D.H. is a founder and shareholder of oNKo-Innate Pty Ltd. The authors declare no other conflict of interest.

\section{References}

1. Rosenberg, S.A.; Packard, B.S.; Aebersold, P.M.; Solomon, D.; Topalian, S.L.; Toy, S.; Simon, P.; Lotze, M.T.; Yang, J.C.; Seipp, C.A.; et al. Use of Tumor-Infiltrating Lymphocytes and Interleukin-2 in the Immunotherapy of Patients with Metastatic Melanoma. N. Engl. J. Med. 1988, 319, 1676-1680. [CrossRef]

2. Hinrichs, C.S.; Rosenberg, S.A. Exploiting the Curative Potential of Adoptive T-Cell Therapy for Cancer. Immunol. Rev. 2014, 257, 56-71. [CrossRef]

3. Johnson, L.A.; June, C.H. Driving Gene-Engineered T Cell Immunotherapy of Cancer. Cell Res. 2017, 27, 38-58. [CrossRef] [PubMed]

4. Gross, G.; Waks, T.; Eshhar, Z. Expression of Immunoglobulin-T-Cell Receptor Chimeric Molecules as Functional Receptors with Antibody-Type Specificity. Proc. Natl. Acad. Sci. USA 1989, 86, 10024-10028. [CrossRef] [PubMed]

5. Eshhar, Z.; Waks, T.; Gross, G.; Schindler, D.G. Specific Activation and Targeting of Cytotoxic Lymphocytes through Chimeric Single Chains Consisting of Antibody-Binding Domains and the $\gamma$ or $\zeta$ Subunits of the Immunoglobulin and T-Cell Receptors. Proc. Natl. Acad. Sci. USA 1993, 90, 720-724. [CrossRef] [PubMed]

6. Maher, J.; Brentjens, R.J.; Gunset, G.; Rivière, I.; Sadelain, M. Human T-Lymphocyte Cytotoxicity and Proliferation Directed by a Single Chimeric TCR乙/CD28 Receptor. Nat. Biotechnol. 2002, 20, 70-75. [CrossRef] [PubMed]

7. Rafiq, S.; Hackett, C.S.; Brentjens, R.J. Engineering Strategies to Overcome the Current Roadblocks in CAR T Cell Therapy. Nat. Rev. Clin. Oncol. 2020, 17, 147-167. [CrossRef]

8. Guedan, S.; Calderon, H.; Posey, A.D.; Maus, M.V. Engineering and Design of Chimeric Antigen Receptors. Mol. Ther. Methods Clin. Dev. 2019, 12, 145-156. [CrossRef]

9. Guest, R.D.; Hawkins, R.E.; Kirillova, N.; Cheadle, E.J.; Arnold, J.; O’Neill, A.; Irlam, J.; Chester, K.A.; Kemshead, J.T.; Shaw, D.M.; et al. The Role of Extracellular Spacer Regions in the Optimal Design of Chimeric Immune Receptors: Evaluation of Four Different ScFvs and Antigens. J. Immunother. 2005, 28, 203-211. [CrossRef]

10. James, S.E.; Greenberg, P.D.; Jensen, M.C.; Lin, Y.; Wang, J.; Till, B.G.; Raubitschek, A.A.; Forman, S.J.; Press, O.W. Antigen Sensitivity of CD22-Specific Chimeric TCR Is Modulated by Target Epitope Distance from the Cell Membrane. J. Immunol. 2008, 180, 7028-7038. [CrossRef]

11. Oei, V.Y.S.; Siernicka, M.; Graczyk-Jarzynka, A.; Hoel, H.J.; Yang, W.; Palacios, D.; Sbak, H.A.; Bajor, M.; Clement, D.; Brandt, L.; et al. Intrinsic Functional Potential of NK-Cell Subsets Constrains Retargeting Driven by Chimeric Antigen Receptors. Cancer Immunol. Res. 2018, 6, 467-480. [CrossRef] [PubMed]

12. Alabanza, L.; Pegues, M.; Geldres, C.; Shi, V.; Wiltzius, J.J.W.; Sievers, S.A.; Yang, S.; Kochenderfer, J.N. Function of Novel Anti-CD19 Chimeric Antigen Receptors with Human Variable Regions Is Affected by Hinge and Transmembrane Domains. Mol. Ther. 2017, 25, 2452-2465. [CrossRef] [PubMed] 
13. Bridgeman, J.S.; Hawkins, R.E.; Bagley, S.; Blaylock, M.; Holland, M.; Gilham, D.E. The Optimal Antigen Response of Chimeric Antigen Receptors Harboring the CD3 $\zeta$ Transmembrane Domain Is Dependent upon Incorporation of the Receptor into the Endogenous TCR/CD3 Complex. J. Immunol. 2010, 184, 6938-6949. [CrossRef] [PubMed]

14. FDA. FDA Approves Tisagenlecleucel for T-Cell ALL and Tocilizumab for Cytokine Release Syndrome; U.S. Food \& Drug Administration: Silver Spring, MD, USA, 2017.

15. FDA. FDA Approves Axicabtagene Ciloleucel for Large B-Cell Lymphoma; U.S. Food \& Drug Administration: Silver Spring, MD, USA, 2017.

16. Hombach, A.A.; Heiders, J.; Foppe, M.; Chmielewski, M.; Abken, H. OX40 Costimulation by a Chimeric Antigen Receptor Abrogates CD28 and IL-2 Induced IL-10 Secretion by Redirected CD4+ T Cells. Oncoimmunology 2012, 1, 458-466. [CrossRef]

17. Guedan, S.; Chen, X.; Madar, A.; Carpenito, C.; McGettigan, S.E.; Frigault, M.J.; Lee, J.; Posey, A.D.; Scholler, J.; Scholler, N.; et al. ICOS-Based Chimeric Antigen Receptors Program Bipolar TH17/ TH1 Cells. Blood 2014, 124, 1070-1080. [CrossRef]

18. Song, D.G.; Powell, D.J. Pro-Survival Signaling via CD27 Costimulation Drives Effective CAR T-Cell Therapy. Oncoimmunology 2012, 1, 547-549. [CrossRef]

19. Salter, A.I.; Ivey, R.G.; Kennedy, J.J.; Voillet, V.; Rajan, A.; Alderman, E.J.; Voytovich, U.J.; Lin, C.; Sommermeyer, D.; Liu, L.; et al. Phosphoproteomic Analysis of Chimeric Antigen Receptor Signaling Reveals Kinetic and Quantitative Differences That Affect Cell Function. Sci. Signal. 2018, 11, eaat6753. [CrossRef]

20. Santomasso, B.; Bachier, C.; Westin, J.; Rezvani, K.; Shpall, E.J. The Other Side of CAR T-Cell Therapy: Cytokine Release Syndrome, Neurologic Toxicity, and Financial Burden. Am. Soc. Clin. Oncol. Educ. Book 2019, 39, 433-444. [CrossRef]

21. Neelapu, S.S.; Locke, F.L.; Bartlett, N.L.; Lekakis, L.J.; Miklos, D.B.; Jacobson, C.A.; Braunschweig, I.; Oluwole, O.O.; Siddiqi, T.; Lin, Y.; et al. Axicabtagene Ciloleucel CAR T-Cell Therapy in Refractory Large B-Cell Lymphoma. N. Engl. J. Med. 2017, 377, 2531-2544. [CrossRef]

22. Depil, S.; Duchateau, P.; Grupp, S.A.; Mufti, G.; Poirot, L. "Off-the-Shelf" Allogeneic CAR T Cells: Development and Challenges. Nat. Rev. Drug Discov. 2020, 19, 185-199. [CrossRef]

23. Lee, D.W.; Gardner, R.; Porter, D.L.; Louis, C.U.; Ahmed, N.; Jensen, M.; Grupp, S.A.; Mackall, C.L. Current Concepts in the Diagnosis and Management of Cytokine Release Syndrome. Blood 2014, 124, 188-196. [CrossRef] [PubMed]

24. Lee, D.W.; Santomasso, B.D.; Locke, F.L.; Ghobadi, A.; Turtle, C.J.; Brudno, J.N.; Maus, M.V.; Park, J.H.; Mead, E.; Pavletic, S.; et al. ASTCT Consensus Grading for Cytokine Release Syndrome and Neurologic Toxicity Associated with Immune Effector Cells. Biol. Blood Marrow Transplant. 2019, 25, 625-638. [CrossRef] [PubMed]

25. Schuster, S.J.; Bishop, M.R.; Tam, C.S.; Waller, E.K.; Borchmann, P.; McGuirk, J.P.; Jäger, U.; Jaglowski, S.; Andreadis, C.; Westin, J.R.; et al. Tisagenlecleucel in Adult Relapsed or Refractory Diffuse Large B-Cell Lymphoma. N. Engl. J. Med. 2019, 380, 45-56. [CrossRef] [PubMed]

26. Maude, S.L.; Laetsch, T.W.; Buechner, J.; Rives, S.; Boyer, M.; Bittencourt, H.; Bader, P.; Verneris, M.R.; Stefanski, H.E.; Myers, G.D.; et al. Tisagenlecleucel in Children and Young Adults with B-Cell Lymphoblastic Leukemia. N. Engl. J. Med. 2018, 378, 439-448. [CrossRef] [PubMed]

27. Park, J.H.; Rivière, I.; Gonen, M.; Wang, X.; Sénéchal, B.; Curran, K.J.; Sauter, C.; Wang, Y.; Santomasso, B.; Mead, E.; et al. Long-Term Follow-up of CD19 CAR Therapy in Acute Lymphoblastic Leukemia. N. Engl. J. Med. 2018, 378, 449-459. [CrossRef]

28. Gardner, R.A.; Finney, O.; Annesley, C.; Brakke, H.; Summers, C.; Leger, K.; Bleakley, M.; Brown, C.; Mgebroff, S.; Kelly-Spratt, K.S.; et al. Intent-to-Treat Leukemia Remission by CD19 CAR T Cells of Defined Formulation and Dose in Children and Young Adults. Blood 2017, 129, 3322-3331. [CrossRef]

29. Teachey, D.T.; Lacey, S.F.; Shaw, P.A.; Melenhorst, J.J.; Maude, S.L.; Frey, N.; Pequignot, E.; Gonzalez, V.E.; Chen, F.; Finklestein, J.; et al. Identification of Predictive Biomarkers for Cytokine Release Syndrome after Chimeric Antigen Receptor T-Cell Therapy for Acute Lymphoblastic Leukemia. Cancer Discov. 2016, 6, 664-679. [CrossRef]

30. Brentjens, R.J.; Davila, M.L.; Riviere, I.; Park, J.; Wang, X.; Cowell, L.G.; Bartido, S.; Stefanski, J.; Taylor, C.; Olszewska, M.; et al. CD19-Targeted T Cells Rapidly Induce Molecular Remissions in Adults with Chemotherapy-Refractory Acute Lymphoblastic Leukemia. Sci. Transl. Med. 2013, 5, 177ra38. [CrossRef] 
31. Porter, D.L.; Hwang, W.T.; Frey, N.V.; Lacey, S.F.; Shaw, P.A.; Loren, A.W.; Bagg, A.; Marcucci, K.T.; Shen, A.; Gonzalez, V.; et al. Chimeric Antigen Receptor T Cells Persist and Induce Sustained Remissions in Relapsed Refractory Chronic Lymphocytic Leukemia. Sci. Transl. Med. 2015, 7, 303ra139. [CrossRef]

32. Neelapu, S.S.; Tummala, S.; Kebriaei, P.; Wierda, W.; Gutierrez, C.; Locke, F.L.; Komanduri, K.V.; Lin, Y.; Jain, N.; Daver, N.; et al. Chimeric Antigen Receptor T-Cell Therapy-Assessment and Management of Toxicities. Nat. Rev. Clin. Oncol. 2018, 15, 47-62. [CrossRef]

33. Kochenderfer, J.N.; Dudley, M.E.; Kassim, S.H.; Somerville, R.P.T.; Carpenter, R.O.; Maryalice, S.S.; Yang, J.C.; Phan, G.Q.; Hughes, M.S.; Sherry, R.M.; et al. Chemotherapy-Refractory Diffuse Large B-Cell Lymphoma and Indolent B-Cell Malignancies Can Be Effectively Treated with Autologous T Cells Expressing an Anti-CD19 Chimeric Antigen Receptor. J. Clin. Oncol. 2015, 33, 540-549. [CrossRef] [PubMed]

34. Santomasso, B.D.; Park, J.H.; Salloum, D.; Riviere, I.; Flynn, J.; Mead, E.; Halton, E.; Wang, X.; Senechal, B.; Purdon, T.; et al. Clinical and Biological Correlates of Neurotoxicity Associated with Car T-Cell Therapy in Patients with B-Cell Acute Lymphoblastic Leukemia. Cancer Discov. 2018, 8, 958-971. [CrossRef] [PubMed]

35. Gust, J.; Hay, K.A.; Hanafi, L.A.; Li, D.; Myerson, D.; Gonzalez-Cuyar, L.F.; Yeung, C.; Liles, W.C.; Wurfel, M.; Lopez, J.A.; et al. Endothelial Activation and Blood-Brain Barrier Disruption in Neurotoxicity after Adoptive Immunotherapy with CD19 CAR-T Cells. Cancer Discov. 2017, 7, 1404-1419. [CrossRef] [PubMed]

36. Wu, C.-Y.; Roybal, K.T.; Puchner, E.M.; Onuffer, J.; Lim, W.A. Remote Control of Therapeutic T Cells through a Small Molecule-Gated Chimeric Receptor. Science 2015, 350, aab4077. [CrossRef]

37. Urbanska, K.; Lanitis, E.; Poussin, M.; Lynn, R.C.; Gavin, B.P.; Kelderman, S.; Yu, J.; Scholler, N.; Powell, D.J. A Universal Strategy for Adoptive Immunotherapy of Cancer through Use of a Novel T-Cell Antigen Receptor. Cancer Res. 2012, 72, 1844-1852. [CrossRef] [PubMed]

38. Rodgers, D.T.; Mazagova, M.; Hampton, E.N.; Cao, Y.; Ramadoss, N.S.; Hardy, I.R.; Schulman, A.; Du, J.; Wang, F.; Singer, O.; et al. Switch-Mediated Activation and Retargeting of CAR-T Cells for B-Cell Malignancies. Proc. Natl. Acad. Sci. USA 2016, 113, E459-E468. [CrossRef]

39. Ma, J.S.Y.; Kim, J.Y.; Kazane, S.A.; Choi, S.H.; Yun, H.Y.; Kim, M.S.; Rodgers, D.T.; Pugh, H.M.; Singer, O.; Sun, S.B.; et al. Versatile Strategy for Controlling the Specificity and Activity of Engineered T Cells. Proc. Natl. Acad. Sci. USA 2016, 113, E450-E458. [CrossRef]

40. Cho, J.H.; Collins, J.J.; Wong, W.W. Universal Chimeric Antigen Receptors for Multiplexed and Logical Control of T Cell Responses. Cell 2018, 173, 1426-1438. [CrossRef]

41. Ruella, M.; Barrett, D.M.; Kenderian, S.S.; Shestova, O.; Hofmann, T.J.; Perazzelli, J.; Klichinsky, M.; Aikawa, V.; Nazimuddin, F.; Kozlowski, M.; et al. Dual CD19 and CD123 Targeting Prevents Antigen-Loss Relapses after CD19-Directed Immunotherapies. J. Clin. Investig. 2016, 126, 3814-3826. [CrossRef]

42. Grada, Z.; Hegde, M.; Byrd, T.; Shaffer, D.R.; Ghazi, A.; Brawley, V.S.; Corder, A.; Schönfeld, K.; Koch, J.; Dotti, G.; et al. TanCAR: A Novel Bispecific Chimeric Antigen Receptor for Cancer Immunotherapy. Mol. Ther. Nucleic Acids 2013, 2, e105. [CrossRef]

43. Hedge, M.; Mukherjee, M.; Grada, Z.; Pignata, A.; Landi, D.; Navai, S.A.; Wakefield, A.; Fousek, K.; Bielamowicz, K.; Chow, K.K.; et al. Tandem CAR T Cells Targeting HER2 and IL13Ra2 Mitigate Tumor Antigen Escape. J. Clin. Investig. 2016, 126, 3036-3052.

44. Lanitis, E.; Poussin, M.; Klattenhoff, A.W.; Song, D.; Sandaltzopoulos, R.; June, C.H.; Powell, D.J. Chimeric Antigen Receptor T Cells with Dissociated Signaling Domains Exhibit Focused Antitumor Activity with Reduced Potential for Toxicity in Vivo. Cancer Immunol. Res. 2013, 1, 43-53. [CrossRef] [PubMed]

45. Kloss, C.C.; Condomines, M.; Cartellieri, M.; Bachmann, M.; Sadelain, M. Combinatorial Antigen Recognition with Balanced Signaling Promotes Selective Tumor Eradication by Engineered T Cells. Nat. Biotechnol. 2013, 31, 71-75. [CrossRef] [PubMed]

46. Roybal, K.T.; Rupp, L.J.; Morsut, L.; Walker, W.J.; McNally, K.A.; Park, J.S.; Lim, W.A. Precision Tumor Recognition by T Cells with Combinatorial Antigen-Sensing Circuits. Cell 2016, 164, 770-779. [CrossRef] [PubMed]

47. Chmielewski, M.; Abken, H. TRUCKs: The Fourth Generation of CARs. Expert Opin. Biol. Ther. 2015, 15, 1145-1154. [CrossRef]

48. Yeku, O.O.; Purdon, T.J.; Koneru, M.; Spriggs, D.; Brentjens, R.J. Armored CAR T Cells Enhance Antitumor Efficacy and Overcome the Tumor Microenvironment. Sci. Rep. 2017, 7, 10541. [CrossRef]

49. Fedorov, V.D.; Themeli, M.; Sadelain, M. PD-1- and CTLA-4-Based Inhibitory Chimeric Antigen Receptors (ICARs) Divert off-Target Immunotherapy Responses. Sci. Transl. Med. 2013, 5, ra172. [CrossRef] 
50. MacKay, M.; Afshinnekoo, E.; Rub, J.; Hassan, C.; Khunte, M.; Baskaran, N.; Owens, B.; Liu, L.; Roboz, G.J.; Guzman, M.L.; et al. The Therapeutic Landscape for Cells Engineered with Chimeric Antigen Receptors. Nat. Biotechnol. 2020, 38, 233-244. [CrossRef]

51. Ruggeri, L.; Capanni, M.; Urbani, E.; Perruccio, K.; Shlomchik, W.D.; Tosti, A.; Posati, S.; Rogaia, D.; Frassoni, F.; Aversa, F.; et al. Effectiveness of Donor Natural Killer Cell Alloreactivity in Mismatched Hematopoietic Transplants. Science 2002, 295, 2097-2100. [CrossRef]

52. Porrata, L.F.; Inwards, D.J.; Ansell, S.M.; Micallef, I.N.; Johnston, P.B.; Gastineau, D.A.; Litzow, M.R.; Winters, J.L.; Markovic, S.N. Early Lymphocyte Recovery Predicts Superior Survival after Autologous Stem Cell Transplantation in Non-Hodgkin Lymphoma: A Prospective Study. Biol. Blood Marrow Transplant. 2008, 14, 807-816. [CrossRef]

53. Majzner, R.G.; Mackall, C.L. Tumor Antigen Escape from CAR T-Cell Therapy. Cancer Discov. 2018, 8, 1219-1226. [CrossRef] [PubMed]

54. Kärre, K.; Ljunggren, H.-G.; Piontek, G.; Kiessling, R. Selective Rejection of H-2-Deficient Lymphoma Variants Suggests Alternative Immune Defence Strategy. Nature 1986, 319, 675-678. [CrossRef] [PubMed]

55. Tallerico, R.; Todaro, M.; Di Franco, S.; Maccalli, C.; Garofalo, C.; Sottile, R.; Palmieri, C.; Tirinato, L.; Pangigadde, P.N.; La Rocca, R.; et al. Human NK Cells Selective Targeting of Colon Cancer-Initiating Cells: A Role for Natural Cytotoxicity Receptors and MHC Class I Molecules. J. Immunol. 2013, 190, 2381-2390. [CrossRef] [PubMed]

56. Castriconi, R.; Daga, A.; Dondero, A.; Zona, G.; Poliani, P.L.; Melotti, A.; Griffero, F.; Marubbi, D.; Spaziante, R.; Bellora, F.; et al. NK Cells Recognize and Kill Human Glioblastoma Cells with Stem Cell-Like Properties. J. Immunol. 2009, 182, 3530-3539. [CrossRef]

57. Yin, T.; Wang, G.; He, S.; Liu, Q.; Sun, J.; Wang, Y. Human Cancer Cells with Stem Cell-like Phenotype Exhibit Enhanced Sensitivity to the Cytotoxicity of IL-2 and IL-15 Activated Natural Killer Cells. Cell. Immunol. 2016, 300, 41-45. [CrossRef]

58. Wang, B.; Wang, Q.; Wang, Z.; Jiang, J.; Yu, S.C.; Ping, Y.F.; Yang, J.; Xu, S.L.; Ye, X.Z.; Xu, C.; et al. Metastatic Consequences of Immune Escape from NK Cell Cytotoxicity by Human Breast Cancer Stem Cells. Cancer Res. 2014, 74, 5746-5757. [CrossRef]

59. Paczulla, A.M.; Rothfelder, K.; Raffel, S.; Konantz, M.; Steinbacher, J.; Wang, H.; Tandler, C.; Mbarga, M.; Schaefer, T.; Falcone, M.; et al. Absence of NKG2D Ligands Defines Leukaemia Stem Cells and Mediates Their Immune Evasion. Nature 2019, 572, 254-259. [CrossRef]

60. Beziat, V.; Liu, L.L.; Malmberg, J.-A.; Ivarsson, M.A.; Sohlberg, E.; Bjorklund, A.T.; Retiere, C.; Sverremark-Ekstrom, E.; Traherne, J.; Ljungman, P.; et al. NK Cell Responses to Cytomegalovirus Infection Lead to Stable Imprints in the Human KIR Repertoire and Involve Activating KIRs. Blood 2013, 121, 2678-2688. [CrossRef]

61. Oberschmidt, O.; Kloess, S.; Koehl, U. Redirected Primary Human Chimeric Antigen Receptor Natural Killer Cells as an "off-the-Shelf Immunotherapy" for Improvement in Cancer Treatment. Front. Immunol. 2017, 8, 654. [CrossRef]

62. Cooper, M.A.; Fehniger, T.A.; Caligiuri, M.A. The Biology of Human Natural Killer-Cell Subsets. Trends Immunol. 2001, 22, 633-640. [CrossRef]

63. Horowitz, A.; Strauss-Albee, D.M.; Leipold, M.; Kubo, J.; Nemat-Gorgani, N.; Dogan, O.C.; Dekker, C.L.; Mackey, S.; Maecker, H.; Swan, G.E.; et al. Genetic and Environmental Determinants of Human NK Cell Diversity Revealed by Mass Cytometry. Sci. Transl. Med. 2013, 5, 1-12. [CrossRef] [PubMed]

64. Mehta, R.S.; Rezvani, K. Chimeric Antigen Receptor Expressing Natural Killer Cells for the Immunotherapy of Cancer. Front. Immunol. 2018, 9, 283. [CrossRef] [PubMed]

65. Zhang, C.; Oberoi, P.; Oelsner, S.; Waldmann, A.; Lindner, A.; Tonn, T.; Wels, W.S. Chimeric Antigen Receptor-Engineered NK-92 Cells: An off-the-Shelf Cellular Therapeutic for Targeted Elimination of Cancer Cells and Induction of Protective Antitumor Immunity. Front. Immunol. 2017, 8, 533. [CrossRef] [PubMed]

66. Gong, J.; Maki, G.; Klingemann, H. Characterization of a Human Cell Line (NK-92) with Phenotypical and Functional Characteristics of Activated Natural Killer Cells Title. Leukemia 1994, 8, 652-658. [PubMed]

67. Tonn, T.; Becker, S.; Esser, R.; Schwabe, D.; Seifried, E. Cellular Immunotherapy of Malignancies Using the Clonal Natural Killer Cell Line NK-92. J. Hematother. Stem Cell Res. 2001, 10, 535-544. [CrossRef]

68. Maki, G.; Klingemann, H.; Martinson, J.; Tam, Y. Factors Regulating the Cytotoxic Activity of the Human Natural Killer Cell Line, NK-92. J. Hematother. Stem Cell Res. 2001, 10, 369-383. [CrossRef] 
69. Jochems, C.; Hodge, J.W.; Fantini, M.; Fujii, R.; Morillon, Y.M.; Greiner, J.W.; Padget, M.R.; Tritsch, S.R.; Tsang, K.Y.; Campbell, K.S.; et al. An NK Cell Line (HaNK) Expressing High Levels of Granzyme and Engineered to Express the High Affinity CD16 Allele. Oncotarget 2016, 7, 86359-86373. [CrossRef]

70. Xu, Y.; Liu, Q.; Zhong, M.; Wang, Z.; Chen, Z.; Zhang, Y.; Xing, H.; Tian, Z.; Tang, K.; Liao, X.; et al. 2B4 Costimulatory Domain Enhancing Cytotoxic Ability of Anti-CD5 Chimeric Antigen Receptor Engineered Natural Killer Cells against T Cell Malignancies. J. Hematol. Oncol. 2019, 12, 49. [CrossRef]

71. Ao, X.; Yang, Y.; Li, W.; Tan, Y.; Guo, W.; Ao, L.; He, X.; Wu, X.; Xia, J.; Xu, X.; et al. Anti-AFR CAR-Engineered NK-92 Cells Display Potent Cytotoxicity Against AFR-Positive Ovarian Cancer. J. Immunother. 2019, 42, 284-296. [CrossRef]

72. Chu, J.; Deng, Y.; Benson, D.M.; He, S.; Hughes, T.; Zhang, J.; Peng, Y.; Mao, H.; Yi, L.; Ghoshal, K.; et al. CS1-Specific Chimeric Antigen Receptor (CAR)-Engineered Natural Killer Cells Enhance in Vitro and in Vivo Antitumor Activity against Human Multiple Myeloma. Leukemia 2014, 28, 917-927. [CrossRef]

73. Guo, C.; Wang, X.; Zhang, H.; Zhi, L.; Lv, T.; Li, M.; Lu, C.; Zhu, W. Structure-Based Rational Design of a Novel Chimeric PD1-NKG2D Receptor for Natural Killer Cells. Mol. Immunol. 2019, 114, 108-113. [CrossRef] [PubMed]

74. Schönfeld, K.; Sahm, C.; Zhang, C.; Naundorf, S.; Brendel, C.; Odendahl, M.; Nowakowska, P.; Bönig, H.; Köhl, U.; Kloess, S.; et al. Selective Inhibition of Tumor Growth by Clonal NK Cells Expressing an ErbB2/HER2-Specific Chimeric Antigen Receptor. Mol. Ther. 2015, 23, 330-338. [CrossRef] [PubMed]

75. Li, Y.; Hermanson, D.L.; Moriarity, B.S.; Kaufman, D.S. Human IPSC-Derived Natural Killer Cells Engineered with Chimeric Antigen Receptors Enhance Anti-Tumor Activity. Cell Stem Cell 2018, 23, 181-192. [CrossRef] [PubMed]

76. MacLeod, R.A.F.; Nagel, S.; Kaufmann, M.; Greulich-Bode, K.; Drexler, H.G. Multicolor-FISH Analysis of a Natural Killer Cell Line (NK-92). Leuk. Res. 2002, 26, 1027-1033. [CrossRef]

77. Tsirigotis, P.; Resnick, I.B.; Kapsimalli, V.; Dray, L.; Psarra, E.; Samuel, S.; Spyridonidis, A.; Konsta, E.; Vikentiou, M.; Or, R.; et al. Irradiated Mononuclear Cells Express Significant in Vitro Cytotoxic Activity: Promise for in Vivo Clinical Efficacy of Irradiated Mismatched Donor Lymphocytes Infusion. Immunotherapy 2014, 6, 409-417. [CrossRef]

78. Zhang, C.; Burger, M.C.; Jennewein, L.; Genßler, S.; Schönfeld, K.; Zeiner, P.; Hattingen, E.; Harter, P.N.; Mittelbronn, M.; Tonn, T.; et al. ErbB2/HER2-Specific NK Cells for Targeted Therapy of Glioblastoma. J. Natl. Cancer Inst. 2016, 108, djv375. [CrossRef]

79. Esser, R.; Müller, T.; Stefes, D.; Kloess, S.; Seidel, D.; Gillies, S.D.; Aperlo-Iffland, C.; Huston, J.S.; Uherek, C.; Schönfeld, K.; et al. NK Cells Engineered to Express a GD 2-Specific Antigen Receptor Display Built-in ADCC-like Activity against Tumour Cells of Neuroectodermal Origin. J. Cell. Mol. Med. 2012, 16, 569-581. [CrossRef]

80. Uherek, C.; Tonn, T.; Uherek, B.; Becker, S.; Schnierle, B.; Klingemann, H.G.; Wels, W. Retargeting of Natural Killer-Cell Cytolytic Activity to ErbB2-Expressing Cancer Cells Results in Efficient and Selective Tumor Cell Destruction. Blood 2002, 100, 1265-1273. [CrossRef]

81. Mitwasi, N.; Feldmann, A.; Arndt, C.; Koristka, S.; Berndt, N.; Jureczek, J.; Loureiro, L.R.; Bergmann, R.; Máthé, D.; Hegedüs, N.; et al. "UniCAR"-Modified off-the-Shelf NK-92 Cells for Targeting of GD2-Expressing Tumour Cells. Sci. Rep. 2020, 10, 2141. [CrossRef]

82. Herrera, L.; Santos, S.; Vesga, M.A.; Anguita, J.; Martin-Ruiz, I.; Carrascosa, T.; Juan, M.; Eguizabal, C. Adult Peripheral Blood and Umbilical Cord Blood NK Cells Are Good Sources for Effective CAR Therapy against CD19 Positive Leukemic Cells. Sci. Rep. 2019, 9, 18729. [CrossRef]

83. Luevano, M.; Daryouzeh, M.; Alnabhan, R.; Querol, S.; Khakoo, S.; Madrigal, A.; Saudemont, A. The Unique Profile of Cord Blood Natural Killer Cells Balances Incomplete Maturation and Effective Killing Function upon Activation. Hum. Immunol. 2012, 73, 248-257. [CrossRef] [PubMed]

84. Wang, Y.; Xu, H.; Zheng, X.; Wei, H.; Sun, R.; Tian, Z. High Expression of NKG2A/CD94 and Low Expression of Granzyme B Are Associated with Reduced Cord Blood NK Cell Activity. Cell. Mol. Immunol. 2007, 4, 377-382.

85. Tanaka, H.; Kai, S.; Yamaguchi, M.; Misawa, M.; Fujimori, Y.; Yamamoto, M.; Hara, H. Analysis of Natural Killer (NK) Cell Activity and Adhesion Molecules on NK Cells from Umbilical Cord Blood. Eur. J. Haematol. 2003, 71, 29-38. [CrossRef] 
86. Dalle, J.H.; Menezes, J.; Wagner, É.; Blagdon, M.; Champagne, J.; Champagne, M.A.; Duval, M. Characterization of Cord Blood Natural Killer Cells: Implications for Transplantation and Neonatal Infections. Pediatr. Res. 2005, 57, 649-655. [CrossRef] [PubMed]

87. Kamiya, T.; Seow, S.V.; Wong, D.; Robinson, M.; Campana, D. Blocking Expression of Inhibitory Receptor NKG2A Overcomes Tumor Resistance to NK Cells. J. Clin. Investig. 2019, 130, 2094-2106. [CrossRef] [PubMed]

88. André, P.; Denis, C.; Soulas, C.; Bourbon-Caillet, C.; Lopez, J.; Arnoux, T.; Bléry, M.; Bonnafous, C.; Gauthier, L.; Morel, A.; et al. Anti-NKG2A MAb Is a Checkpoint Inhibitor That Promotes Anti-Tumor Immunity by Unleashing Both T and NK Cells. Cell 2018, 175, 1731-1743. [CrossRef]

89. Liu, E.; Marin, D.; Banerjee, P.; Macapinlac, H.A.; Thompson, P.; Basar, R.; Nassif Kerbauy, L.; Overman, B.; Thall, P.; Kaplan, M.; et al. Use of CAR-Transduced Natural Killer Cells in CD19-Positive Lymphoid Tumors. N. Engl. J. Med. 2020, 382, 545-553. [CrossRef]

90. Björkström, N.K.; Riese, P.; Heuts, F.; Andersson, S.; Fauriat, C.; Ivarsson, M.; Björklund, A.T.; Flodström-Tullberg, M.; Michaëlsson, J.; Rottenberg, M.E.; et al. Expression Patterns of NKG2A, KIR, and CD57 Define a Process of CD56dim NK Cell Differentiation Uncoupled from NK-Cell Education. Blood 2010, 116, 3853-3864. [CrossRef]

91. Miller, J.S.; Soignier, Y.; Panoskaltsis-Mortari, A.; McNearney, S.A.; Yun, G.H.; Fautsch, S.K.; McKenna, D.; Le, C.; Defor, T.E.; Burns, L.J.; et al. Successful Adoptive Transfer and in Vivo Expansion of Human Haploidentical NK Cells in Patients with Cancer. Blood 2005, 105, 3051-3057. [CrossRef]

92. Björklund, A.T.; Carlsten, M.; Sohlberg, E.; Liu, L.L.; Clancy, T.; Karimi, M.; Cooley, S.; Miller, J.S.; Klimkowska, M.; Schaffer, M.; et al. Complete Remission with Reduction of High-Risk Clones Following Haploidentical NK-Cell Therapy against MDS and AML. Clin. Cancer Res. 2018, 24, 1834-1844. [CrossRef]

93. Curti, A.; Ruggeri, L.; Parisi, S.; Bontadini, A.; Dan, E.; Motta, M.R.; Rizzi, S.; Trabanelli, S.; Ocadlikova, D.; Lecciso, M.; et al. Larger Size of Donor Alloreactive NK Cell Repertoire Correlates with Better Response to NK Cell Immunotherapy in Elderly Acute Myeloid Leukemia Patients. Clin. Cancer Res. 2016, 22, 1-8. [CrossRef] [PubMed]

94. Knorr, D.A.; Ni, Z.; Hermanson, D.; Hexum, M.K.; Bendzick, L.; Cooper, L.J.N.; Lee, D.A.; Kaufman, D.S. Clinical-Scale Derivation of Natural Killer Cells From Human Pluripotent Stem Cells for Cancer Therapy. Stem Cells Transl. Med. 2013, 2, 274-283. [CrossRef] [PubMed]

95. Valamehr, B.; Robinson, M.; Abujarour, R.; Rezner, B.; Vranceanu, F.; Le, T.; Medcalf, A.; Lee, T.T.; Fitch, M.; Robbins, D.; et al. Platform for Induction and Maintenance of Transgene-Free HiPSCs Resembling Ground State Pluripotent Stem Cells. Stem Cell Rep. 2014, 2, 366-381. [CrossRef] [PubMed]

96. Hermanson, D.L.; Bendzick, L.; Pribyl, L.; McCullar, V.; Isaksson Vogel, R.; Miller, J.S.; Geller, M.A.; Kaufman, D.S. Induced Pluripotent Stem Cell-Derived Natural Killer Cells for Treatment of Ovarian Cancer. Stem Cells 2016, 34, 93-101. [CrossRef] [PubMed]

97. Saetersmoen, M.L.; Hammer, Q.; Valamehr, B.; Kaufman, D.S.; Malmberg, K.J. Off-the-Shelf Cell Therapy with Induced Pluripotent Stem Cell-Derived Natural Killer Cells. Semin. Immunopathol. 2019, 41, 59-68. [CrossRef] [PubMed]

98. Carlsten, M.; Childs, R.W. Genetic Manipulation of NK Cells for Cancer Immunotherapy: Techniques and Clinical Implications. Front. Immunol. 2015, 6, 266. [CrossRef] [PubMed]

99. Miller, D.G.; Adam, M.A.; Miller, A.D. Gene Transfer by Retrovirus Vectors Occurs Only in Cells That Are Actively Replicating at the Time of Infection. Mol. Cell. Biol. 1990, 10, 4239-4242. [CrossRef]

100. Lin, C.; Zhang, J. Reformation in Chimeric Antigen Receptor Based Cancer Immunotherapy: Redirecting Natural Killer Cell. Biochim. Biophys. Acta 2018, 1869, 200-215. [CrossRef]

101. Davis, H.E.; Morgan, J.R.; Yarmush, M.L. Polybrene Increases Retrovirus Gene Transfer Efficiency by Enhancing Receptor-Independent Virus Adsorption on Target Cell Membranes. Biophys. Chem. 2002, 97, 159-172. [CrossRef]

102. Haneberg, H.; Xiao, X.L.; Dilloo, D.; Hashino, K.; Kato, I.; Williams, D.A. Colocalization of Retrovirus and Target Cells on Specific Fibronectin Fragments Increases Genetic Transduction of Mammalian Cells. Nat. Med. 1996, 2, 876-882. [CrossRef]

103. Lowe, E.; Truscott, L.C.; De Oliveira, S.N. In Vitro Generation of Human NK Cells Expressing Chimeric Antigen Receptor Through Differentiation of Gene-Modified Hematopoietic Stem Cells BT-Natural Killer Cells: Methods and Protocols; Somanchi, S.S., Ed.; Springer: New York, NY, USA, 2016; pp. 241-251. [CrossRef] 
104. Fenard, D.; Ingrao, D.; Seye, A.; Buisset, J.; Genries, S.; Martin, S.; Kichler, A.; Galy, A. Vectofusin-1, a New Viral Entry Enhancer, Strongly Promotes Lentiviral Transduction of Human Hematopoietic Stem Cells. Mol. Ther. Nucleic Acids 2013, 2, e90. [CrossRef] [PubMed]

105. Colamartino, A.B.; Lemieux, W.; Bifsha, P.; Nicoletti, S.; Chakravarti, N.; Sanz, J.; Romero, H.; Selleri, S.; Beland, K.; Guiot, M.; et al. Efficient and Robust NK-Cell Transduction with Baboon Envelope Pseudotyped Lentivector. Front. Immunol. 2019, 10, 2873. [CrossRef] [PubMed]

106. Sutlu, T.; Nyström, S.; Gilljam, M.; Stellan, B.; Applequist, S.E.; Alici, E. Inhibition of Intracellular Antiviral Defense Mechanisms Augments Lentiviral Transduction of Human Natural Killer Cells: Implications for Gene Therapy. Hum. Gene Ther. 2012, 23, 1090-1100. [CrossRef] [PubMed]

107. Micucci, F.; Zingoni, A.; Piccoli, M.; Frati, L.; Santoni, A.; Galandrini, R. High-Efficient Lentiviral Vector-Mediated Gene Transfer into Primary Human NK Cells. Exp. Hematol. 2006, 34, 1344-1352. [CrossRef] [PubMed]

108. Chang, Y.H.; Connolly, J.; Shimasaki, N.; Mimura, K.; Kono, K.; Campana, D. A Chimeric Receptor with NKG2D Specificity Enhances Natural Killer Cell Activation and Killing of Tumor Cells. Cancer Res. 2013, 73, 1777-1786. [CrossRef]

109. Xiao, L.; Cen, D.; Gan, H.; Sun, Y.; Huang, N.; Xiong, H.; Jin, Q.; Su, L.; Liu, X.; Wang, K.; et al. Adoptive Transfer of NKG2D CAR MRNA-Engineered Natural Killer Cells in Colorectal Cancer Patients. Mol. Ther. 2019, 27, 1114-1125. [CrossRef]

110. Li, L.; Liu, L.N.; Feller, S.; Allen, C.; Shivakumar, R.; Fratantoni, J.; Wolfraim, L.A.; Fujisaki, H.; Campana, D.; Chopas, N.; et al. Expression of Chimeric Antigen Receptors in Natural Killer Cells with a Regulatory-Compliant Non-Viral Method. Cancer Gene Ther. 2010, 17, 147-154. [CrossRef]

111. Boissel, L.; Betancur, M.; Wels, W.S.; Tuncer, H.; Klingemann, H. Transfection with MRNA for CD19 Specific Chimeric Antigen Receptor Restores NK Cell Mediated Killing of CLL Cells. Leuk. Res. 2009, 33, 1255-1259. [CrossRef]

112. Kebriaei, P.; Izsvák, Z.; Narayanavari, S.A.; Singh, H.; Ivics, Z. Gene Therapy with the Sleeping Beauty Transposon System. Trends Genet. 2017, 33, 852-870. [CrossRef]

113. Ivics, Z.; Hackett, P.B.; Plasterk, R.H.; Izsvák, Z. Molecular Reconstruction of Sleeping Beauty, a Tc1-like Transposon from Fish, and Its Transposition in Human Cells. Cell 1997, 91, 501-510. [CrossRef]

114. Zayed, H.; Izsvák, Z.; Walisco, O.; Ivics, Z. Development of Hyperactive Sleeping Beauty Transposon Vectors by Mutational Analysis. Mol. Ther. 2004, 9, 292-304. [CrossRef] [PubMed]

115. Rostovskaya, M.; Fu, J.; Obst, M.; Baer, I.; Weidlich, S.; Wang, H.; Smith, A.J.H.; Anastassiadis, K.; Francis Stewart, A. Transposon-Mediated BAC Transgenesis in Human ES Cells. Nucleic Acids Res. 2012, 40, e150. [CrossRef] [PubMed]

116. Monjezi, R.; Miskey, C.; Gogishvili, T.; Schleef, M.; Schmeer, M.; Einsele, H.; Ivics, Z.; Hudecek, M. Enhanced CAR T-Cell Engineering Using Non-Viral Sleeping Beauty Transposition from Minicircle Vectors. Leukemia 2017, 31, 186-194. [CrossRef] [PubMed]

117. Querques, I.; Mades, A.; Zuliani, C.; Miskey, C.; Alb, M.; Grueso, E.; Machwirth, M.; Rausch, T.; Einsele, H.; Ivics, Z.; et al. A Highly Soluble Sleeping Beauty Transposase Improves Control of Gene Insertion. Nat. Biotechnol. 2019, 37, 1502-1512. [CrossRef] [PubMed]

118. Roth, T.L.; Puig-Saus, C.; Yu, R.; Shifrut, E.; Carnevale, J.; Li, P.J.; Hiatt, J.; Saco, J.; Krystofinski, P.; Li, H.; et al. Reprogramming Human T Cell Function and Specificity with Non-Viral Genome Targeting. Nature 2018, 559, 405-409. [CrossRef]

119. Osborn, M.J.; Webber, B.R.; Knipping, F.; Lonetree, C.L.; Tennis, N.; DeFeo, A.P.; McElroy, A.N.; Starker, C.G.; Lee, C.; Merkel, S.; et al. Evaluation of TCR Gene Editing Achieved by TALENs, CRISPR/Cas9, and MegaTAL Nucleases. Mol. Ther. 2016, 24, 570-581. [CrossRef]

120. Georgiadis, C.; Preece, R.; Nickolay, L.; Etuk, A.; Petrova, A.; Ladon, D.; Danyi, A.; Humphryes-Kirilov, N.; Ajetunmobi, A.; Kim, D.; et al. Long Terminal Repeat CRISPR-CAR-Coupled “Universal” T Cells Mediate Potent Anti-Leukemic Effects. Mol. Ther. 2018, 26, 1215-1227. [CrossRef]

121. Granzin, M.; Wagner, J.; Köhl, U.; Cerwenka, A.; Huppert, V.; Ullrich, E. Shaping of Natural Killer Cell Antitumor Activity by Ex Vivo Cultivation. Front. Immunol. 2017, 8, 458. [CrossRef]

122. Cooper, M.A.; Elliott, J.M.; Keyel, P.A.; Yang, L.; Carrero, J.A.; Yokoyama, W.M. Cytokine-Induced Memory-like Natural Killer Cells. Proc. Natl. Acad. Sci. USA 2009, 106, 1915-1919. [CrossRef] 
123. Ni, J.; Miller, M.; Stojanovic, A.; Garbi, N.; Cerwenka, A. Sustained Effector Function of IL-12/15/18Preactivated NK Cells against Established Tumors. J. Exp. Med. 2012, 209, 2351-2365. [CrossRef]

124. Boieri, M.; Ulvmoen, A.; Sudworth, A.; Lendrem, C.; Collin, M.; Dickinson, A.M.; Kveberg, L.; Inngjerdingen, M. IL-12, IL-15, and IL-18 Pre-Activated NK Cells Target Resistant T Cell Acute Lymphoblastic Leukemia and Delay Leukemia Development in Vivo. Oncoimmunology 2017, 6, e1274478. [CrossRef] [PubMed]

125. Ni, J.; Hölsken, O.; Miller, M.; Hammer, Q.; Luetke-Eversloh, M.; Romagnani, C.; Cerwenka, A. Adoptively Transferred Natural Killer Cells Maintain Long-Term Antitumor Activity by Epigenetic Imprinting and CD4+ T Cell Help. Oncoimmunology 2016, 5, e1219009. [CrossRef] [PubMed]

126. Romee, R.; Schneider, S.E.; Leong, J.W.; Chase, J.M.; Keppel, C.R.; Sullivan, R.P.; Cooper, M.A.; Fehniger, T.A. Cytokine Activation Induces Human Memory-like NK Cells. Blood 2012, 120, 4751-4760. [CrossRef] [PubMed]

127. Romee, R.; Rosario, M.; Berrien-Elliott, M.M.; Wagner, J.A.; Jewel, B.A.; Schappe, T.; Leong, J.W.; Abdel-Latif, S.; Schneider, S.E.; Willey, S.; et al. Cytokine-Induced Memory-like Natural Killer Cells Exhibit Enhanced Responses against Myeloid Leukemia. Sci. Transl. Med. 2016, 8, 1-12. [CrossRef] [PubMed]

128. Pfefferle, A.; Jacobs, B.; Netskar, H.; Ask, E.H.; Lorenz, S.; Clancy, T.; Goodridge, J.P.; Sohlberg, E.; Malmberg, K.J. Intra-Lineage Plasticity and Functional Reprogramming Maintain Natural Killer Cell Repertoire Diversity. Cell Rep. 2019, 29, 2284-2294. [CrossRef]

129. Jacobs, B.; Pfefferle, A.; Clement, D.; Berg-Larsen, A.; Saetersmoen, M.L.; Lorenz, S.; Wiiger, M.T.; Goodridge, J.P.; Malmberg, K.-J. Induction of the BIM Short Splice Variant Sensitizes Proliferating NK Cells to IL-15 Withdrawal. J. Immunol. 2019, 202, 736-746. [CrossRef]

130. Bae, D.S.; Lee, J.K. Development of NK Cell Expansion Methods Using Feeder Cells from Human Myelogenous Leukemia Cell Line. Blood Res. 2014, 49, 154-161. [CrossRef]

131. Berg, M.; Lundqvist, A.; Mc Coy, P., Jr.; Samsel, L.; Fan, Y.; Tawab, A.; Childs, R. Clinical Grade Ex Vivo-Expanded Human Natural Killer Cells Upregulate Activating Receptors and Death Receptor Ligands and Have Enhanced Cytolytic Activity against Tumor Cells. Cytotherapy 2009, 11, 341-355. [CrossRef]

132. Liu, L.L.; Béziat, V.; Oei, V.Y.S.; Pfefferle, A.; Schaffer, M.; Lehmann, S.; Hellström-Lindberg, E.; Söderhäll, S.; Heyman, M.; Grandér, D.; et al. Ex Vivo Expanded Adaptive NK Cells Effectively Kill Primary Acute Lymphoblastic Leukemia Cells. Cancer Immunol. Res. 2017, 5, 654-665. [CrossRef]

133. Lapteva, N.; Szmania, S.M.; van Rhee, F.; Rooney, C.M. Clinical Grade Purification and Expansion of Natural Killer Cells. Crit. Rev. Oncog. 2014, 19, 121-132. [CrossRef]

134. Li, Q.; Ye, L.J.; Ren, H.L.; Huyan, T.; Li, J.; Shi, J.L.; Huang, Q.S. Multiple Effects of IL-21 on Human NK Cells in Ex Vivo Expansion. Immunobiology 2015, 220, 876-888. [CrossRef] [PubMed]

135. Kweon, S.; Phan, M.T.T.; Chun, S.; Yu, H.B.; Kim, J.; Kim, S.; Lee, J.; Ali, A.K.; Lee, S.H.; Kim, S.K.; et al. Expansion of Human NK Cells Using K562 Cells Expressing OX40 Ligand and Short Exposure to IL-21. Front. Immunol. 2019, 10, 879. [CrossRef] [PubMed]

136. Denman, C.J.; Senyukov, V.V.; Somanchi, S.S.; Phatarpekar, P.V.; Kopp, L.M.; Johnson, J.L.; Singh, H.; Hurton, L.; Maiti, S.N.; Huls, M.H.; et al. Membrane-Bound IL-21 Promotes Sustained Ex Vivo Proliferation of Human Natural Killer Cells. PLoS ONE 2012, 7, e30264. [CrossRef] [PubMed]

137. Vidard, L.; Dureuil, C.; Baudhuin, J.; Vescovi, L.; Durand, L.; Sierra, V.; Parmantier, E. CD137 (4-1BB) Engagement Fine-Tunes Synergistic IL-15- and IL-21-Driven NK Cell Proliferation. J. Immunol. 2019, 203, 676-685. [CrossRef] [PubMed]

138. Bachanova, V.; Cooley, S.; Defor, T.E.; Verneris, M.R.; Zhang, B.; McKenna, D.H.; Curtsinger, J.; Panoskaltssi-Mortari, A.; Lewis, D.; Hippen, K.; et al. Clearance of Acute Myeloid Leukemia by Haploidentical Natural Killer Cells Is Improved Using IL-2 Diphtheria Toxin Fusion Protein. Blood 2014, 123, 3855-3863. [CrossRef]

139. Jiang, T.; Zhou, C.; Ren, S. Role of IL-2 in Cancer Immunotherapy. Oncoimmunology 2016, 5, e1163462. [CrossRef]

140. Ahmadzadeh, M.; Rosenberg, S.A. IL-2 Administration Increases CD4+CD25hi Foxp3 + Regulatory T Cells in Cancer Patients. Blood 2006, 107, 2409-2414. [CrossRef] 
141. Conlon, K.C.; Lugli, E.; Welles, H.C.; Rosenberg, S.A.; Fojo, A.T.; Morris, J.C.; Fleisher, T.A.; Dubois, S.P.; Perera, L.P.; Stewart, D.M.; et al. Redistribution, Hyperproliferation, Activation of Natural Killer Cells and CD8 T Cells, and Cytokine Production during First-in-Human Clinical Trial of Recombinant Human Interleukin-15 in Patients with Cancer. J. Clin. Oncol. 2015, 33, 74-82. [CrossRef]

142. Lugli, E.; Goldman, C.K.; Perera, L.P.; Smedley, J.; Pung, R.; Yovandich, J.L.; Creekmore, S.P.; Waldmann, T.A.; Roederer, M. Transient and Persistent Effects of IL-15 on Lymphocyte Homeostasis in Nonhuman Primates. Blood 2010, 116, 3238-3248. [CrossRef]

143. Lang, S.; Vujanovic, N.L.; Wollenberg, B.; Whiteside, T.L. Absence of B7.1-CD28/CTLA-4-Mediated Co-Stimulation in Human NK Cells. Eur. J. Immunol. 1998, 28, 780-786. [CrossRef]

144. Lanier, L.L. NK Cell Recognition. Annu. Rev. Immunol. 2005, 23, 225-274. [CrossRef] [PubMed]

145. Imai, C.; Iwamoto, S.; Campana, D. Genetic Modification of Primary Natural Killer Cells Overcomes Inhibitory Signals and Induces Specific Killing of Leukemic Cells. Blood 2005, 106, 376-383. [CrossRef] [PubMed]

146. Töpfer, K.; Cartellieri, M.; Michen, S.; Wiedemuth, R.; Müller, N.; Lindemann, D.; Bachmann, M.; Füssel, M.; Schackert, G.; Temme, A. DAP12-Based Activating Chimeric Antigen Receptor for NK Cell Tumor Immunotherapy. J. Immunol. 2015, 194, 3201-3212. [CrossRef] [PubMed]

147. Endt, J.; Eissmann, P.; Hoffmann, S.C.; Meinke, S.; Giese, T.; Watzl, C. Modulation of 2B4 (CD244) Activity and Regulated SAP Expression in Human NK Cells. Eur. J. Immunol. 2007, 37, 193-198. [CrossRef]

148. Liu, E.; Tong, Y.; Dotti, G.; Shaim, H.; Savoldo, B.; Mukherjee, M.; Orange, J.; Wan, X.; Lu, X.; Reynolds, A.; et al. Cord Blood NK Cells Engineered to Express IL-15 and a CD19-Targeted CAR Show Long-Term Persistence and Potent Antitumor Activity. Leukemia 2018, 32, 520-531. [CrossRef]

149. Tang, X.; Yang, L.; Li, Z.; Nalin, A.P.; Dai, H.; Xu, T.; Yin, J.; You, F.; Zhu, M.; Shen, W.; et al. First-in-Man Clinical Trial of CAR NK-92 Cells: Safety Test of CD33-CAR NK-92 Cells in Patients with Relapsed and Refractory Acute Myeloid Leukemia. Am. J. Cancer Res. 2018, 8, 2018.

150. Goodridge, J.P.; Jacobs, B.; Saetersmoen, M.L.; Clement, D.; Hammer, Q.; Clancy, T.; Skarpen, E.; Brech, A.; Landskron, J.; Grimm, C.; et al. Remodeling of Secretory Lysosomes during Education Tunes Functional Potential in NK Cells. Nat. Commun. 2019, 10, 1-15. [CrossRef]

151. Goodridge, J.P.; Önfelt, B.; Malmberg, K.-J. Newtonian Cell Interactions Shape Natural Killer Cell Education. Immunol. Rev. 2015, 267, 197-213. [CrossRef] 